NBER WORKING PAPER SERIES

\title{
BANK EXAMINERS' INFORMATION AND EXPERTISE AND THEIR ROLE IN MONITORING AND DISCIPLINING BANKS BEFORE AND DURING THE PANIC OF 1893
}

\author{
Charles W. Calomiris \\ Mark Carlson \\ Working Paper 24460 \\ http://www.nber.org/papers/w24460 \\ NATIONAL BUREAU OF ECONOMIC RESEARCH \\ 1050 Massachusetts Avenue \\ Cambridge, MA 02138 \\ March 2018
}

The views expressed herein are those of the authors and do not necessarily reflect the views of the National Bureau of Economic Research or of the Board of Governors of the Federal Reserve System and its staff.

NBER working papers are circulated for discussion and comment purposes. They have not been peer-reviewed or been subject to the review by the NBER Board of Directors that accompanies official NBER publications.

(C) 2018 by Charles W. Calomiris and Mark Carlson. All rights reserved. Short sections of text, not to exceed two paragraphs, may be quoted without explicit permission provided that full credit, including $\odot$ notice, is given to the source. 
Bank Examiners' Information and Expertise and Their Role in Monitoring and Disciplining Banks Before and During the Panic of 1893

Charles W. Calomiris and Mark Carlson

NBER Working Paper No. 24460

March 2018

JEL No. G21,G28,N21,N41

\begin{abstract}
We examine whether examiners were informed and contributed to the health of the banking sector. Information included quantitative information that was eventually made public, quantitative information that remained private, and subjective information dependent on the examiner's production of additional, "soft" information that informed examiner assessments of the quality of bank assets and management. All three types of information were useful for gauging the condition of the bank, and affected bank behavior, including a publicly observable signal (skipping a dividend payment). Participants in the market for bank liabilities reacted to this signal in ways that promoted market discipline.

Charles W. Calomiris

Columbia Business School

3022 Broadway Street, Uris Hall

New York, NY 10027

and NBER

cc374@columbia.edu

Mark Carlson

Federal Reserve Board

20th and Constitution Ave., NW

Washington, DC 20551

mark.a.carlson@frb.gov
\end{abstract}




\section{Introduction}

The supervision and examination of commercial banks by trained examiners is a key component of efforts by regulatory authorities to promote the health and stability of the financial sector. Nonetheless, the impact that examiners have is not well understood, in part because of the confidentiality of the process and of the outcomes. Previous work has found that examinations produce useful information about bank condition, but has offered only modest insights into the mechanisms at work. Some studies find that bank examiners collect valuable private information, which inform regulatory ratings of bank health, which are useful in forecasting asset prices and changes in the condition of the bank (Berger and Davis 1994; DeYoung, Flannery, Lang, and Sorescu 1998, Goldsmith-Pinkham, Hirtle, and Lucca 2016). These studies, however, do not provide evidence about whether and how this information is used by supervisors or markets to affect bank behavior. ${ }^{1}$ Other studies have found that banks subject to more intensive examinations tend to have lower loan delinquency rates (Rezende and Wu 2014; Hirtle, Kovner, and Plosser 2016), but the mechanism by which this happens remains unclear.

In this paper, we are able to use detailed records of bank examinations to provide insights into the types of information possessed by the examiner and illuminate how that information was used to influence the actions taken by the bank. The bank examination records we use are from the examinations of National banks by examiners in the United States Office of the Comptroller of the Currency (OCC) during the National Banking Era (1863-1913) which are publicly available in the National Archives. Looking at these reports allows us to see the sorts of information that the examiners were collecting and observe how the examiners put together different pieces of information to arrive at an overall assessment of the condition of the bank and make their recommendations. Moreover, by observing sequential examination reports, we are also able to observe the response by banks to the recommendations of the examiners.

The National Banking Era was the first time that widespread and systematic use of bank examiners was employed in the U.S. Despite periodic panics that would temporarily close large parts of the banking system, the failure rate of National banks was fairly low and comparable to that of the modern era. The analysis here sheds light on whether the examiners had a role in

\footnotetext{
${ }^{1}$ Flannery, Hirtle and Kovner (2017) show that stress test results influence market perceptions of banks, providing evidence of a likely synergy between regulatory and market discipline.
} 
keeping the bank failure rate low. There is little existing evidence about the effectiveness of National bank examinations. In his Annual Reports, the Comptroller of the Currency, the head of the OCC, praised examiners, but also call for improvements in the examination process (1887, 1889, 1891). Crays (1941) argues that the bank examiners during this period paid close attention to the health of banks in order to protect the payment system. White (1983) notes that the National banks had a much better reputation than state banks, in part because of the examination process; but he also notes that the policy of the time of paying examiners based on the number of banks that they examined may have reduced the incentive to conduct thorough and high quality examinations. Moreover, in 1892, there were nearly 3,800 National banks to be examined and 41 examiners. As each examiner had to examine over 90 banks, on average, they would have needed to conduct their investigations at a fairly rapid pace and it is not certain how thorough they would have been able to be.

From an analytical standpoint, the examination process during this time period has some desirable features. First, banks were examined roughly once each year irrespective of their prior observed condition, which mitigates some of the endogeneity concerns that arise in modern studies where troubled banks tend to be examined more frequently than other banks. Second, one of the typical disciplinary recommendations by examiners was that the bank suspend the payment of dividends. Such an action was publically observable. Thus, we are able to study the impact of having some information about the results of the examination revealed to the market (albeit imperfectly, as there were other reasons that banks may have opted to skip paying dividends).

We start our analysis by considering the sorts of information generated by the examination process. We categorize this information as being either quantitative information that the examiner was required to collect, or soft information based on the judgment and skill of the examiner. These two types of information reflect different aspects of the examination process. Quantitative information would not necessarily require an expert to obtain it. For instance, examiners were asked to state whether the president of the bank had to post a performance bond and to provide the value of loans that met a statutory definition of being delinquent. In contrast, to be useful, soft information in the report requires expertise on the part of the examiner. For instance, the examiners were asked to comment on whether the 
management was capable, whether the board of directors was exercising oversight, and whether loans were adequately secured. This information may have been valuable in evaluating the health of the bank, but its production required training and judgment.

As we consider the value of the information in the examination report, we recognize that there were other sources of information about the health of banks. Five times a year, the Comptroller required banks to file a report of condition covering basic balance sheet information (the Call Report), and this report was also required to be published in a local newspaper. The Comptroller also included one of these reports for each bank in his published annual report. The information contained in these public balance sheets also presumably shed light on the condition of the banks. A subset of the quantitative information in the examination report is the same as the information disclosed to the public. Thus, we categorize the quantitative information in the examination report as either publically observable information or as private information.

A summary statistic of the examiner's evaluation of the condition of the bank was the estimated losses the bank was likely to incur on its assets. This loss estimate was central to the examiner's determination of whether to recommend that the bank be disciplined, such as by requiring it to suspend the payment of dividends or write down the value of its capital. Using the examination reports from 1892 for a sample of banks in larger cities in the South and West of the United States, we decompose the estimated losses into three parts associated with (1) the quantitative balance sheet that was made available to the public, (2) the quantitative information only available in the examination report, and (3) the soft information residual, which we attribute to the judgment of the examiner. We show that our residual is correlated with subjective assessments reported in the examination report, such as whether, in the examiner's opinion, the management was "capable and prudent.”

We then test whether these three components have predictive power for three bank outcomes. $^{2}$ Our first outcome measure is whether the bank survived the panic of 1893, one of the most severe stress events of the National Banking Era. The second measure is an indicator of bank profitability between 1892 and 1894: the growth rate of surplus and undivided profits. The third measure, the change between 1892 and 1894 in the ratio of other real estate owned

${ }^{2}$ This methodology is similar to the one used by DeYoung, Flannery, Lang, and Sorescu (1998). 
(typically collateral seized when a loan went bad) relative to assets, is an indicator of loan performance.

We find that all three component parts of estimated losses are useful for predicting our outcome measures. Finding that the part of estimated losses attributable to public information is informative confirms contemporary assessments (and recent academic research) that the holders of bank liabilities (both depositors and other banks) found the information in the Call Report useful for evaluating the health of the banks (Calomiris and Mason 1997, Calomiris and Mason 2003, Carlson 2005, DeYoung, Flannery, Lang, and Sorescu 1998, White 1984). Finding that private quantitative data from the examination report has predictive power indicates that examiners collected useful additional hard information during examinations, such as information about assets, as well as measures of corporate governance choices (see also Calomiris and Carlson 2016). Finally, that the residual soft information is informative indicates that the examiner’s training and judgment were valuable for producing information.

We are able to investigate whether individual examiners were particularly tough or easy. We find that, in general, the examiners appear to have been fairly uniform in their translation of balance sheet metrics into loss estimates. The loss estimates from the few examiners that were either particularly easy or tough do not display significantly differential predictive power for bank outcomes.

Finally we look at whether the examiners were able to use their assessments about the condition of the bank to take actions that promoted bank health and resiliency. The examiners did not have many remedial recommendations available to them. One recommendation that they did often make, if their loss estimate was sufficiently large, was for the bank to skip its dividend payment and use the additional retained earnings to cover charge offs of bad loans. Even controlling for other factors, we find that such a recommendation increased the likelihood that the bank did skip its divided by 23 percent. Furthermore, banks for whom the examiner recommended that dividends be skipped tended to charge-off losses to a greater degree than other banks. ${ }^{3}$

\footnotetext{
${ }^{3}$ Hirtle, Kovner, and Plosser (2016) find that modern banks that receive more regulatory scrutiny tend to have more conservative loan loss provisioning practices. Thus, both their results and our results suggest that one channel through which examiners played a role is through the managing of losses.
} 
In addition, it appears that the examination report may have provided a signal to the public that could have been used to support market discipline. Banks that skipped paying a dividend tended to pay higher rates for funds than other banks. If an unfavorable examination report raised the likelihood that banks skipped paying a dividend and potentially increased borrowing costs for the bank, then the examination process and market discipline would have reinforced each other. ${ }^{4}$ This signal, and the interaction with market discipline, is similar to the findings of Flannery, Hirtle, and Kovner (2017) that bank equity prices respond to the news contained in the modern Federal Reserve stress tests.

Overall, our results indicate that the examiners in the National Banking Era were a valuable part of the information collection process, both through their access to objective information about assets and banking practices, and through their processing of soft information. We also find that this information was used to discipline banks, and that regulatory discipline (reflected in dividend suspension) had implications for additional market discipline.

The paper is organized as follows. Section 2 describes the data that we use in our analysis, as well as the examination process that created the data. Section 3 discusses the methodology that we use to evaluate the usefulness of different types of information available to and provided by the examiners. Section 4 reports empirical results. In Section 5, we test whether individual examiners differed in their toughness, and investigate whether those differences mattered for the predictive content of their judgments. Section 6 describes how the monitoring of the examiners was related to the discipline of poorly performing banks. Section 7 concludes.

\section{Data}

The data we use come primarily from the examination reports prepared in the early 1890s by the OCC examiners. The examination reports were quite detailed and, in this section, we describe the parts of these reports that are salient for our analysis. We also use data from the Reports of Condition or "Call Reports" from the same period and describe that information briefly as well.

\footnotetext{
${ }^{4}$ There were other reasons why banks might not pay a dividend. For instance, newer banks tended to omit them in favor of building up their surplus and undivided profits.
} 
Given that gathering information from examination reports for all national banks would be prohibitively time consuming, we focus on a particular, and important, subset of National banks in our analysis, namely banks located in important western and southern cities. We explain the desirability of focusing on this group of banks in Section 2.2.

\subsection{Primary data sources}

Examination reports were written by the field examiners hired by the OCC. The information in these reports reflects the private information of the examiner after looking over the books of the bank - typically over a two day period. The examination reports are a rich source of information that cover many aspects of the operations of the National banks, including the structure and quality of corporate ownership and governance, the distribution and quality of the loan book, amounts of assets related to real estate, and the composition of liabilities. ${ }^{5}$ Some material the examiner collected was quantifiable, such as the value of loans for which real estate served as collateral or whether there was a loan and discount review committee with at least one board member who was not a manager. Other information was much more subjective, such as requests for the examiner to comment on the "general character of loans" or whether the bank officers were “capable, prudent, and of good reputation.”

At the end of the report, the examiners were asked to provide a quantitative assessment of the likely losses that the bank faced. The loss estimates could be related to loans that were considered "bad" or were likely to have to be written down, or to problems with other assets, such as an over-valued banking house or real estate that had been acquired when a borrower had defaulted. Such assets generally were liquidated at less than the value at which they were carried on the books. Based on these loss estimates, the examiner might recommend that the bank take action to set aside resources to write-off bad assets, or if losses were severe, write down the value of its capital.

The second source of data is the Report of Condition, or "Call Report" which was a report of the balance sheet of the bank provided to the OCC about five times a year. A copy of each report was retained on site and the examiner could check this report against the books of the

\footnotetext{
${ }^{5}$ Calomiris and Carlson (2014) in particular provide a detailed summary of the contents of the Examination Reports during this period. See also Robertson (1968) for more information on the examination process.
} 
bank as well as use the information to compare against the current condition of the bank. ${ }^{6}$ The information in the call report was public. In fact, banks were required to publish some basic line items from the call report in a local newspaper about the time it was sent to the Comptroller. In his Annual Report, the Comptroller also included the call reports for all the national banks for one of the five filing dates. This information was reportedly used by the public and other banks to monitor the condition of individual banks and was considered useful information about the health of the bank. Indeed, the information about the balance sheets of all individual banks in the annual report was considered valuable enough that the Comptroller considered publishing this volume twice a year (Comptroller of the Currency 1890).

We are interested in how the information in these two sources is related to how the banks fared in and after the Panic of 1893 . Therefore, we (mainly) use the examination and call reports that mostly closely precede the Panic. The Call Report is only available once per year and we use the September 1892 Call report. For the examination report, we use the examination report that started closest to, but not after, May 1, 1893 (just before the onset of the Panic).

\subsection{The sample}

The sample consists of 205 national banks drawn from 37 cities. During this time, National banks operated as "unit" banks with a single bank location. The cities include all the reserve cities and a number of the larger cities in the Southern and Western part of the country. ${ }^{7}$ We focus on this region because it was the most seriously affected during the Panic of 1893; this event will provide a test of the value of the information collected by the examiners. Indeed, nearly all the cities in our sample had at least one bank close during the panic. The banks in the sample comprise all the National banks that were located in these cities that both filed a September 1892 Call Report and had an examination report prior to May 1, 1893.

The banks in the sample are generally comparable in size. They range from $\$ 200,000$ in assets to $\$ 8,000,000$. Thus, the sample excludes the tails of the banking system, the largest

\footnotetext{
${ }^{6}$ It is noteworthy that examiners were also asked to verify the information provided on the call report. Doing so ensured that the information being reported there was accurate and thus useful. We are not able to measure this benefit, but it would be in addition to the other benefits noted elsewhere in the paper.

${ }^{7}$ Reserve cities were officially designated as such. Interbank deposits placed in the National banks located in Reserve cities could be counted as part of the legal reserve of other national banks.
} 
money center banks and small banks operating in small communities. Additionally, as the banks in the sample are in either reserve cities or larger cities, they also likely had access to broadly comparable ranges of business opportunities. Thus, the banks in the sample are generally comparable to each other. It is important to note that our sample reflects a particular slice of the banking system at the time, an important slice consisting of the institutions connecting the periphery to the center, but a slice nonetheless.

\subsection{The examination process}

Examiners were generally assigned to a region and in charge of reviewing the banks in that region. We find that, when visiting a town, the examiners would typically look at several banks. White (1983) points out that examiners were paid by the number of banks that they examined and that the examiners had to pay their own expenses, which creates an incentive for the examiners to minimize the number of days spent traveling. If the town had only a few banks, then the examiner would look at them all. However, we also observe that, if the town had a more substantial number of banks, perhaps six or more, then the examiners would generally break up the examinations. He would typically examine several banks, then leave to look at banks elsewhere, and return a few months later to examine the rest of the banks. The examinations typically took two days, although they could be done in a single day or take as long as five days.

As noted by White (2009), one concern about the process of looking at multiple banks in a town at the same time is that once banks learned that at examiner was in town, they might have “window dressed” their balance sheets to make the condition of the bank appear more favorable. This could lead to biased comparisons among banks based on the sequence of examination. In the Appendix, we consider this potential for window dressing bias and show that it does not appear to be important, given that it was not visible in bank cash holdings (where it should be particularly pronounced).

We also considered whether examiner turnover might be endogenous to the severity of examiners' opinions. If so, it is conceivable that turnover could be associated with reduced examiner discipline, which might bias comparisons of examinations across banks that does not take account of such bias. In the Appendix, we consider this possibility, and find no evidence that examiner turnover resulted from relatively negative examination reports. 


\section{Methodology}

In this section, we describe two methodological approaches to evaluate the usefulness of the information collected by the examiners. We also describe in more detail the variables used in the analysis.

\subsection{Methodological approaches}

We are interested in whether the private information on the examination reports was useful in assessing the condition of and prospects for the banks above and beyond the public Call Report information available from the banks and the Comptroller's office. In addition, we are interested in whether both the quantifiable information in the examination report and the soft information the examiner collected during his assessment of the bank are useful for forecasting bank outcomes.

\subsubsection{Decomposition approach}

The foundation of both approaches is the loss estimates provided by the examiner. These estimates provided a numerical summary of the overall condition of the bank. The estimates were central to supporting any recommendation the examiner might make about whether to discipline the bank and to determining the particular type of discipline to impose (suspension of dividends, capital write-down). Thus, the examiners presumably took considerable care when making these estimates. ${ }^{8}$

We start our analysis by decomposing the loss estimates into the portions that can be attributed to each of our three sets of information: the quantifiable information observable to the public from the Call Report and bank location, the quantifiable information observed only by the examiner that was contained in the examination report, and soft information the examiner. Here we follow a similar procedure has been used elsewhere in the literature to extract the portion of

\footnotetext{
${ }^{8}$ Examiners were expected to have some knowledge of the quality of the local businesses to help them make these evaluations and loss estimates. One examiner indicated that he was new to the city in which he was examining banks and reported that he had sought out the local agent from Bradstreet's, a private credit rating agency, to help him evaluate the quality of the loan book. (Examiner report of the North Texas National Bank of Dallas, TX, charter 3834, 3/2/1893).
} 
quantitative ratings due to private information (DeYoung et al. 1998). The decomposition is done by orthogonalizing the three sets of influences on the loss estimate. Orthogonalization permits us to compare the relative importance of the three influences in our regression analysis. The orthogonalization requires us to pick an ordering between the two quantitative influences, and we believe it is natural to put the public information first in the ordering, which attributes any covariation between the two to public information. This provides a conservative assessment of the role of the examination process. ${ }^{9}$

In the first step of the orthogonalization, we regress the loss estimates on publicly available information both balance sheet variables and location attributes:

Loss estimate $=\alpha_{1}+\beta_{1}$ Call report vars $+\beta_{2}$ Location $+\varepsilon$

The predicted values from this regression are the part of losses that are attributed to public information while the residual $(\varepsilon)$ is the part of the loss estimate related to the private information of the examiner (quantitative and soft) that is orthogonal to the public information.

In the second step, we regress $\varepsilon$ on the private quantitative information.

$\varepsilon=\alpha_{2}+\beta_{3}$ Exam report vars $+\tau$

The predicted values from this regression are the part of losses that are attributed to private quantitative information while the residual $(\tau)$ represents the portion of losses that we attribute to the examiner’s soft information. To be precise, our decomposition approach gives us:

$L_{1}=$ losses attrbiuted to public data $=\widehat{\alpha_{1}}+\widehat{\beta_{1}}$ Call report vars $+\widehat{\beta_{2}}$ Location

$L_{2}=$ losses attributed to "quantifiable" private data $=\widehat{\alpha_{2}}+\widehat{\beta_{3}}$ Exam report vars

$L_{3}=$ losses attributed to "soft" private data $=\tau$

\footnotetext{
${ }^{9}$ As a robustness check, we switched the order of orthogonalization to place the quantitative information from the examination first. We continue to find that both sets of information are valuable and that there were only minor changes in the relative importance of public vs. private information.
} 
Having decomposed expected losses in this way, we then investigate whether any of the component parts are related to the subsequent performance of the bank, either during the panic or over the next two years.

Outcome $=f\left(\alpha_{3}+\beta_{4} L_{1}+\beta_{5} L_{2}+\beta_{6} L_{3}\right)$

If the loss estimates contain any information useful for forecasting the evolution of the condition of the bank, then one or more of the three components should be associated with the subsequent outcomes.

\subsubsection{Direct prediction approach}

The above methodological approach we employ uses the information available to the examiners to explore whether the examiner's ex ante expectations of performance are related to subsequent bank performance. An alternative (direct prediction) approach estimates the relationship between the observable information of all kinds and performance measures with the benefit of hindsight available to us as researchers to see whether the component of the loss estimate attributed to the soft private information of the examiner $(\tau)$ is useful in predicting outcomes as well as to determine the value of the data collected by the examiners. Here we would estimate:

Outcome $=f\left(\gamma_{1} \tau+\gamma_{2}\right.$ Exam report vars $+\gamma_{3}$ Call report vars $+\gamma_{4}$ Location $)$

Thus we have two different approaches for assessing the value the soft information provided by the examiners.

\subsection{What variables should be informative?}

When considering the kinds of variables that we should expect to matter in our analysis, and the context in which they will matter, it is helpful to think of risk at three levels: loan level risk, asset level risk (of which a subset is loan level risk), and institution level risk (of which a subset is asset level risk).

The examiner was asked to estimate expected losses for the assets, not just the loans, of the bank. To do so, they considered the riskiness of the loan book, which they observed directly. They considered loan delinquencies and the adequacy of any collateral when estimating losses. 
Additionally, they might also have taken into account corporate governance practices (such as the practices of the loan committee, if any) that could impact the riskiness of the loan book, such as the strength of checks and balances embedded in the loan approval process. The examiners would also have evaluated potential losses from other non-loan assets of the bank, such as the bank building and furnishings, and the assets held by the bank that were acquired from foreclosing on loans.

In addition to asset losses, there are a variety of other variables that would be expected to matter for some of the outcomes that we observe, which outsiders should find useful to consider when evaluating the riskiness of the bank, even if these were not part of the examiners' asset loss estimates. An obvious example is the leverage of the bank. Leverage positively affects the default risk of the bank; more leveraged banks should be more likely to fail in the event of a given shock to the value of assets. In addition, leverage could be a sign of a bank's willingness to take risk, which outsiders might use as a signal of the otherwise unobservable riskiness of the bank's loan portfolio. However, because the examiners observe the loan portfolio directly and are familiar with management practices of the bank, we expect that leverage would not be especially helpful for them in predicting the asset losses of the bank. We include leverage and other non-asset institutional level risk measures, such as deposit composition, in our regressions of loss estimates just in case the examiner took some signal from them, but we do not expect them to matter in those regressions.

Our two procedures approach the value of soft versus quantitative information, and their implications for bank outcomes, in different but complementary ways. Our decomposition approach uses only examiner knowledge. This approach focuses on how outcomes are related to risks that appear on the asset side of the balance sheet (loan level and asset level risk), as perceived by the examiner. The alternative approach allows us to assess more broadly the value of pieces of information ex post. It compares the value of subjective information against a holistic picture of the bank's failure risk (not just asset loss risk) and considers how failure risk relates to different outcomes.

\subsection{Variables}


We have three sets of information: public quantifiable information, which consists of both call report data and location variables; private quantifiable information based on quantifiable information in the examination reports; and private soft information where we do not use any observable information. Here we describe the variables we construct for each of the three sets.

\subsubsection{Public quantifiable items from the call report}

We construct several variables from information reported in the Call Report. We consider these to be both publicly observable and "hard" quantifiable information. The variables we use have clear interpretations and many have been found to be associated with failure risk in prior studies.

The first of these variables is bank size, which we measure using the log of total assets. Larger banks presumably can diversify loan risk better, and may have greater ability to pick higher quality managers, and therefore, may have lower expected losses.

A direct indicator of the quality of the assets of the banks available from the call report is “other real estate owned," which typically measures real estate acquired by a bank after a loan went bad. We expect such loans to be predictive of higher expected losses. Another asset side variable that we employ is the ratio of cash to assets. Cash holdings are riskless and thus reduce asset default risk. They also reduce liquidity risk by enhancing the ability of the bank to meet obligations as they come due. While not as riskless as vault cash, interbank deposits are also fairly safe and liquid, so we include the ratio of interbank deposits to assets. Interbank deposits might also provide a signal about risk preferences; Calomiris, Heider, and Hoerova (2017) suggest that banks that hold more cash assets (especially when those cash assets are held in a verifiable form outside the bank, such as interbank deposits) may be incentivized to manage loan risk more conservatively.

We also include variables related to the funding profile of the bank. These variables may be relevant either because of their contribution to liquidity risk, or because their presence is correlated with otherwise unobservable asset risks. Bills payable and/or rediscounts are higher cost forms of funding and borrowing through these instruments was considered imprudent in 
many cases. ${ }^{10}$ Reliance on this funding source has been found by prior studies to predict bank failure during the National Banking Era, as well as during subsequent periods (Calomiris and Mason 1997, 2003, Carlson 2005). Bank reliance on this high cost source of funding may have provided information about bank management or risk preferences, leading examiners to expect higher asset losses even though there is no direct connection between this variable and asset losses. For that reason, we add an indicator for whether the bank borrowed money in this way. We also include the ratio of individual deposits to total liabilities. While it is not obvious whether this variable would necessarily be linked to failure, the examiner might have considered the role of individual depositors in funding base of the bank when estimating losses.

Our final call report variable is the bank's capital ratio, defined as the ratio of net worth—capital, surplus, and undivided profits—-to assets. As discussed above, while this variable does not directly affect the asset risk of the bank, lower leverage may be correlated with otherwise unobservable expected asset losses.

\subsubsection{Public quantifiable items linked to bank demographics and location}

Various other bank attributes and locational factors would have been apparent to both the examiners and the general public, and therefore, should be included as control variables. We classify several control variables as publicly available information. Older banks might have more experienced personal and be better run. We thus include the log of the age of the bank as an observable attribute.

The interbank deposits placed in other National banks located in reserve cities were allowed to count toward National banks’ reserve requirements. Given their systemic importance,, examiners may have subjected reserve city banks to greater scrutiny. We control for this possibility by including an indicator variable for whether the National bank was located in a reserve city. There is some indication from prior studies that banks located farther west tended to behave differently (Calomiris and Carlson 2016), so we also control for the distance the city is away from New York City, the center of the financial system.

\footnotetext{
${ }^{10}$ However, it was not uncommon for banks to resort to using these sources of funds during the harvest season. Use of such borrowing for these purposes was generally understood to be less problematic.
} 
County population size also may have mattered; larger populations might contain more lending opportunities, which might in turn have meant that banks could choose from a better pool of potential borrowers. We therefore add a control variable to account for the (log of the) county population. Similarly, the types of nearby lending opportunities might also have shaped loss expectations. In particular, the large seasonal swings associated with agriculture, or the potentially volatile nature of mining, may have been viewed as informative of asset risk by examiners. Thus we include variables indicating the importance of agriculture in the state economy and an indicator for whether the state had notable mining activities (at least $\$ 1$ million in gold or silver was mined in the state in 1891).

\subsubsection{Private quantifiable items linked to the examination report}

The reports that the examiners filed with the Comptroller contained considerably more information about the condition of the bank than was available through the Call Report. This information, in combination with the examiner's recommendations, could be used by the Comptroller to determine whether to take disciplinary action against the bank, or could inform decisions regarding the renewal of charters (during the National Banking Era, bank charters had to be renewed every 20 years). There are a number of quantifiable items in the examination report that the examiners might have used to inform their estimates of losses.

As noted above, certain loans were specified as meeting a statutory definition of being "bad." For loans that were bad based on objective specifications, it did not take an expert to determine whether the loans were problematic, although judgment was still necessary to estimate expected losses. We use the share of total loans that consisted of these technically bad loans as one private quantitative measure the examiner could have considered when forming loss estimates.

We also include ratios related to particular loan categories that were observed by the examiner. Real estate loans were considered riskier loans and National banks were forbidden from originating loans secured by real estate collateral. National banks were however, allowed to take real estate collateral to secure previously existing debts. We therefore include the portion of loans backed by real estate as another quantitative indicator the examiner may have considered when estimating losses. Another type of loan listed on the examination report was 
demand loans, which are loans that could be called for repayment at the discretion of the bank. Comments by the examiner suggest that these were viewed as offering more liquidity to the bank than time loans. It is possible that the examiner considered these loans of a different credit quality, and also may have seen them as reducing liquidity risk.

We also include variables related to the governance and operation of the bank, which prior work has shown may matter for risk taking. One governance variable is the share of the bank's equity owned by managers in the top three officer positions (president, vice-president, and cashier). Calomiris and Carlson (2016) find that banks for which the three top officers owned a greater proportion of bank shares tended to be more conservatively run institutions. The number of shares owned by these individuals was listed in the examination report, and the total number of shares could be observed easily because total shares equal the paid-in-capital of the bank divided by one-hundred. ${ }^{11}$ We also considered governance measures that indicate whether non-management shareholders were monitoring the management. These include whether the president needed to post a performance bond (as a device for managing fraud), the log of the number of meetings the board held each year (based on whether the examiner whether the board met weekly, monthly, semi-annually, etc.), and whether there was an independent discount committee that monitored the loans. All three of these items were specifically required to be stated in the examination report. ${ }^{12}$

Finally, we include two other measures related to the liabilities of the banks. First, one item described in the examination report was whether the bank issued certificates of deposit "for the purpose of borrowing money.” These were CDs that were issued to other banks and secured. They paid higher rates of interest than interbank deposits, but lower rates of interest than bills payable. Comments from the examiners make it clear that these CDs often were a close substitute for bills payable or rediscounts, but structured in such a way as to avoid being required to be reported as one of those more suspect items. Coffin (1890) provides a dim view on the use

\footnotetext{
${ }^{11}$ In a few instances, the book value of the shares was not equal to one hundred, but these were noted in the call report.

${ }^{12}$ Calomiris and Carlson (2016) use the sum of five indicators based on these pieces of information as well as whether the cashier had to post a performance bond and the share of the board of directors that consisted of nonmanagers. We use individual governance characteristics here as the examiner may have put different weights on different attributes than the equal weighting used by Calomiris and Carlson.
} 
of these certificates as a signal of bank risk. Thus, having information on the use of such liabilities by the bank might be indicative of riskier behavior.

Second, the examination reports provide more detailed information regarding the composition of individual deposits than the call report. Recent research, such as Ramierez and Zandbergen (2013), have found that individuals’ checking deposits were a more stable funding source during crisis episodes than other deposits. It is unclear whether contemporaries would have made this inference, nevertheless, we include the ratio of checking deposits to total individual deposits as another indicator available from the examination report that is potentially related to the riskiness of the bank.

\subsubsection{Outcome variables}

We focus on three outcome variables. The first is whether or not the bank closesdefined as fails, suspends temporarily, or otherwise ceases operation-between the September 1892 call report (or most recent examiner report) and the end of 1893, after the panic. The use of this broad measure of closure to measure the failure of banks does not distinguish among many possible definitions of "failure.” A bank could fail (be liquidated by regulators) if the regulators decide to take possession of the bank and appoint an outside receiver to liquidate the institution; this typically occurred if losses were expected to exceed the net worth of the bank. A voluntary liquidation would occur if the owners of the bank decided to unwind the bank without the regulators appointing a receiver; this could occur if the bank had incurred losses that were not so severe as to completely wipe out equity. Potentially, a bank could also be voluntarily liquidated if the owners simply decided that the bank was no longer expected to be profitable, although there is not much sign of this in our sample. Finally, a bank could suspend operations temporarily. This might occur if there was a "run” on the bank in which liability holders sought to withdraw more cash than the bank had available, forcing the bank could shut its doors. If the owners desired to reopen, the examiners were sent to evaluate the bank to verify that its condition was generally sound and then would give permission.

Rather than try to distinguish among these various cases of bank "failure.” we focus simply on whether any of these events occurred. In our sample, 16 banks were placed in receivership, 7 were voluntarily liquidated, and 35 suspended temporarily but reopened. In 
general, higher loss estimates of any sort should be associated with an increased likelihood of closure.

The other two outcome variables capture bank performance following the panic. These measures, therefore, are observed conditional on the bank having survived the panic. The first is the change in the ratio of other real estate owned relative to assets between the September 1892 call report and October 1894 call report. As other real estate owned is associated with the seizing of collateral once a loan has gone bad, a change in this ratio is indicative of an improvement or deterioration in the health of the bank's loan portfolio. We expect that the change in other real estate owned will be relatively greater for banks with higher expected losses.

The last outcome variable is the percent change in the bank's surplus and undivided profits between the 1892 and 1894 call reports. These balance sheet items reflect the retained earnings of the bank. An increase in these items could be a sign of a more profitable bank. The existence of current retained earnings also affected banks' ability to write off bad loans without reducing surplus and undivided profits. If current those profits were insufficient to cover loan losses, then the bank would write-down its surplus and undivided profits to cover write-offs of bad assets. Higher expected losses would be linked to both higher write-offs and lower accumulations of income, so we expect a negative association between the growth of surplus and undivided profits and different measures of expected losses.

Definitions of all variables appear in Table 1. Summary statistics are reported in Table 2.

\section{Analysis of the value of examiner private information}

Here we present our baseline results as well as a variety of robustness exercises.

\subsection{Analysis using the decomposition approach}

Beginning with the decomposition approach, we estimate equation 1 to analyze how publicly available information contributed to the examiner estimates of total losses. These results are reported in Table 3 . The adjusted $\mathrm{R}^{2}$ of the regression indicates that more than onethird of the variation in loan loss estimates can be explained by publicly observable information. Only one of the balance sheet variables from the call report is statistically significant; the ratio of other real estate owned (OREO) is strongly and positively related to estimated losses. Given that 
these assets were the result of loans that went bad, this result is not surprising. Locational attributes (country and state characteristics and the reserve city indictor) played a notable role in determining the examiner loss estimates. As expected, we find that banks in reserve cities tended to have lower estimated losses than other institutions. Examiners appear to have had a more positive views of mining activities as banks in areas where mining was more prevalent tended to have lower expected losses. Agricultural activity appears to have been more suspect as examiners tended to increase estimates of expected greater losses at banks in areas where agriculture was more important. Estimated losses also tended be higher in more populous areas.

The role of non-public quantifiable factors available from the examination report in explaining the part of losses not explained by public information (equation 2) is shown in Table 4. ${ }^{13}$ The adjusted $\mathrm{R}^{2}$ is 0.13 which indicates that the variables reflecting private quantitative information explain an appreciable share of the residual from the first stage. Banks that had more loans secured by real estate were expected to have higher losses. Additionally, banks that funded themselves with certificates of deposit issued to other banks were also expected to have higher losses. Observing the use of such liabilities seems to have led the examiner to be more skeptical of the quality of the assets the bank was reporting. Banks that made use of formal corporate governance tools, such as having an independent loan review committee or requiring the president of the bank to post a performance bond, were considered by the examiner to have lower expected losses, ceteris paribus. There is one puzzling result: banks for which the board met more frequently were expected to have higher asset losses; this finding suggests that involvement of the directors may have been viewed as a response to greater risk.

The residual from the second stage is our measure of the loss estimate that is related to the soft information of the examiner that is used in his assessment of the condition of the bank. To assure ourselves that we are in fact capturing something associated with the expertise and perceptiveness of the examiner, we examine how this residual is related to some of the characterizations made in the examination report that illustrate aspects of "soft" information. One useful characterization is whether the management was viewed by the examiner as capable and efficient, both subjective ideas. For the 25 banks for which the examiner had concerns about

\footnotetext{
13 The standard errors from this regression are determined using a bootstrap approach that estimates
} equations 1 and 2 jointly for 500 repetitions. 
the capability and efficiency of the management, the average residual is 0.013 . At the other banks, the residual has an average value of -0.002. (The difference is significant at the 1 percent level.) The higher residual at banks were the examiner had concerns about the quality of the management is consistent with the idea that the residual is capturing some of the "soft" information from the examiner about the quality of management.

Overall these results suggest that both the public and private quantitative information were incorporated into the loss estimates provided by the examiner, but that there was still substantial room for soft information to play a role in the examiner’s loss estimate.

We next turn to testing whether the three decomposed parts of the loss estimate are useful in predicting the outcome measures. The results of regressing the three outcome measures on the loss estimate components are shown in Table 5. ${ }^{14}$ The results confirm that all three components contributed to loss forecasts. The coefficients on all three components have the expected signs in all cases. Higher expected losses raise the likelihood of failure, reduce the growth rate of surplus and undivided profits, and are associated with having an increase in other real estate owned on the bank's books. ${ }^{15}$

We find that that the loss estimate that we attribute to "soft" private information has useful predictive power. A one standard deviation increase in the expected losses attributable to soft private information (.027) increased the likelihood that the bank closed by about 11 percentage points; thus the effect is economically large. We also find that the loss estimate based on soft information helps predict the future performance of the bank. A one standard

\footnotetext{
${ }^{14}$ The standard errors in Table 5 are determined using a bootstrap approach that estimates the first, second, and third stage jointly (estimation of equations 1, 2, and 3) for 500 repetitions. In each of these repetitions, we impose the constraint that the number of failed banks is not too low, which would cause problems in estimating the bank closure regressions, nor too high, which would cause problems estimating the regressions involving the change in net worth and change in other real estate owned. For the closure regressions, we report raw probit coefficients in the Table to facilitate comparison with the bootstrapped standard errors while the text describes the marginal effects.

${ }^{15}$ We examined how much the three components contribute to the $\mathrm{R}^{2}$ of these regressions. We find that the public information was most informative and accounted for about 80 percent of the pseudo $\mathrm{R}^{2}$ of the failure regression, about 35 percent of the adjusted $\mathrm{R}^{2}$ of the change in new worth regression, and about 45 percent of the change in OREO regression. Soft information was also fairly informative and accounted for about 45 percent of the explanatory part of the change in OREO regression and about 10 percent of the overall explanatory power for the other two regression. Private quantitative information contributes about half of the explanatory power for the regression involving the change in net worth and about 10 percent of the explanatory power for the other two regressions.
} 
deviation increase in this type of estimated loss is associated with a reduction in the growth of surplus and undivided profits of 28 percentage points (a bit less than one standard deviation) and boosts the change in other real estate owned by about 1 percentage point (about half a standard deviation).

The part of total expected losses attributed to private quantifiable information has predictive power for the two outcome measures that are available for banks that survive the panic, but has less predictive power for closure around the time of the panic. A one standard deviation increase in this component (0.012) is associated with a reduction in the growth of surplus and undivided profits of 18 percentage points and with a boost in the change in other real estate owned by .6 percentage points (about one-fourth of a standard deviation). Thus, the size of the effects are slightly less than for the part of losses due to soft information.

The part of total expected losses that are attributable to public information and location effects are particularly valuable for predicting closure. Here a one standard deviation increase in this measure (0.024) is associated with an increase in the probability of failure of 16 percentage points. The connection to the subsequent change in retained earnings is also quite strong. The coefficient implies that a one-standard deviation increase in this component of expected losses reduces growth in in surplus and undivided profits by 28 percentage points. Interestingly, we find no relationship between this part of estimated losses and the change in other real estate owned.

These results show that the soft information provided by the examiners was quite useful in assessing the health of the bank. The soft information appears to be statistically related to our three outcome measures and has comparably sized effects as the other components of the loss estimate.

\subsection{Analysis using the direct prediction approach}

We now turn to our alternative (direct prediction) framework and test whether the component of losses attributable to soft information has predictive power for various outcomes after accounting for the public and private quantifiable information directly. The results of regressing our outcome measures on the component of losses associated with soft information, 
the quantitative indicators of bank condition, and locational attributes are shown in Table $6 .{ }^{16}$ The first column of the Table displays results when the outcome variable is closure during the Panic of 1893, the second column has results for when the outcome is the growth of surplus and undivided profits, and the third column reports results when the outcome is the change in other real estate owned. ${ }^{17}$

The results in these tables support the view that soft information provides important information about the condition of the bank. The component of losses we attribute to the examiner's judgment continues to forecast the outcome variables despite the fact that the quantitative variables are now able to forecast directly the outcome variables, rather than acting through their impact on the examiner's expected losses. The sizes of the soft information coefficients are not greatly changed, indicating that the economic size of the relationships remain similar in this approach as in the previous approach.

The other variables in the regressions affect outcomes in ways consistent with our expectations. Using money borrowed from other banks, either via certificates of deposit or bills payable and rediscounts, provided a negative signal about growth in surplus and undivided profits. Notably, the coefficients on these variables in this case are nearly identical. This result is consistent with the statements in the examination reports that these two forms of borrowing were close substitutes.

\footnotetext{
${ }^{16}$ The standard errors in Table 6 are determined using a bootstrap approach that estimates the first, second, and third stage jointly (estimation of equations 1, 2, and 4) for 500 repetitions. In each of these repetitions, we impose the constraint that the number of failed banks is not to low, which would cause problems in estimating the bank closure regressions, nor too high, which would cause problems estimating the regressions involving the change in net worth and change in other real estate owned. For the closure regressions, we report raw probit coefficients in the Table to facilitate comparison with the bootstrapped standard errors while the text describes the marginal effects.

${ }^{17}$ We make one modest change to the independent variables in the regression for the change in OREO. Because the dependent variable is the change in the ratio of OREO to assets from 1892 to 1894, including the ratio for 1892 on the right hand side in a linear specification would mean that we are estimating the effect of the other independent variables of the ratio in 1894 rather than on the change. Instead, we substitute an indicator variable for whether the bank had an 1892 ratio in excess of the median ratio. As an alternative, we tried estimating a Tobit regression using the level of the 1894 ratio and using the 1892 ratio as a control. That specification produced similar qualitative results.
} 
Banks that had more net worth relative to their assets (i.e. were less leveraged) were less likely to fail during the crisis. These banks also tended to experience greater increases in their other real estate owned over the next couple years.

The impact of greater involvement in real estate proved to be mixed, but was generally detrimental. Banks with more other real estate owned (loans gone bad and collateral seized) on their balance sheets in 1892 were more likely to close. Both a greater share of loans that consisted of real estate loans and having more other real estate owned are associated with lower growth in surplus and undivided profits. Banks with high levels of other real estate owned in 1892 also tended to see larger increases in this ratio by 1894 .

The deposit base also mattered for the outcomes we consider. Banks that were funded more by individual deposits appear to have done better in surviving the panic. Banks with more checking deposits tended to have stronger growth in retained earnings and lower growth in their other real estate owned.

With respect to corporate governance, we find that banks that required that the president be bonded tended to experience slower growth in other real estate owned in subsequent years. Our other corporate governance variables are not significant predictors.

Location mattered. Banks in reserve cities were less likely to close and tended to fare better after the Panic, with greater increases in their surplus and undivided profits. Banks in states with large mining activity tended to have higher growth in their surplus and undivided profits following the panic while banks in more populated areas had lower growth.

\subsection{Comparison to modern results}

Our finding that examiners during the National Banking Era had valuable private knowledge (both because of private hard information, and because of private soft information) is in line with research regarding the information produced by modern examiners. Berger and Davis (1994) find that downgrades of regulatory ratings (which are not observed by the public) tend to occur in advance of declines in equity prices. Their result suggests that examiners have private information, especially with regard to potential deteriorations in condition. DeYoung, Flannery, Lang, and Sorescu (1998) regress regulatory CAMEL rating on publicly observable 
information and see if the residuals have information for future movements of the prices of subordinated debt. They find that the residuals have predictive power, which provides evidence that the examiners possess useful private information.

Goldsmith-Pinkham, Hirtle, and Lucca (2016), look at the types of information possessed by examiners; they find that examiners pay attention to information about internal processes, internal controls, and regulatory compliance, but that the assessments of information about capital and liquidity seem more closely associated with deteriorations in bank health. Similarly, we find that measures of capital and liquidity, as reflected in the examiner assessments, mattered for bank outcomes. However, our results put more weight on the value of internal controls. We find that measures of governance and internal controls are strongly associated with the examiner's estimates to total losses and that even our measures of soft information appears to be correlated with indicators related to concerns about the quality of the management.

\subsection{Examiners' errors}

All of this is not to say that examiners were perfect. Bank managers appear to have been able to hide problems in their institutions if they were particularly determined to do so. One illustrative example is the Indianapolis National Bank. Two successive examiners reported that the bank appeared to be in good shape. The examiner in June 1892 reported that the bank was in good condition and was prosperous. On July 17, 1893, the examiner reported that the bank was "in excellent condition." Seven days later the bank failed. There was a run which closed the bank on July $24 .{ }^{18}$ A receiver was appointed on August 3. By the end of 1900, the receiver had returned to depositors only 60 cents on the dollar, which was low by the standards of other National bank failures; White (2017) calculates that payout rates averaged around 70 percent for much of the National Banking era. The bank president had apparently been engaging in numerous deceptive practices to support the failing business of his sons. These practices included issuing small loans to all the employees of these businesses to make it look like the loans were better distributed and inflating the value of collateral. Detecting fraud can always be

\footnotetext{
${ }^{18}$ Other banks also appear to have thought the bank was not in terrible shape. The Indianapolis Journal of July 26, p.1, reported that the clearinghouse of the city had extended the bank a \$50,000 loan when the run first started a few days previous.
} 
a challenge and clearly the examiners missed this particular episode. We provide this example to highlight the challenges of processing soft information.

\section{Did examiner identity matter?}

We know the names of the examiners that conducted each examination. ${ }^{19}$ Here we investigate whether expected losses contained an examiner fixed effect, and whether these fixed effects mattered for gauging the relationship between expected losses and bank outcomes. If so, then it may be desirable to include examiner fixed effects in the regressions.

To test for differences in examiner strictness, we create indicator variables for each examiner that performed at least five examinations. There were 18 examinations that were made by six individuals that conducted less than five examinations each; these form the control group against which we compare the other examiners. We then regress estimated total losses on these examiner indicator variables, along with the quantitative variables used above, both public and private, and locational controls.

The results are reported in Table 7. In most cases, we find that the coefficients on the examiner indicator variables are small and insignificant. This finding suggests that, broadly speaking, banks were held to a fairly uniform standard.

There are a few exceptions. Mr. Stone and Mr. Gannon appear to have been relatively tough while Mr. Brush and Mr. Chamber were comparatively easy. We looked at whether the banks that these individuals examined fared worse or better in any of our measures. To do so, we regress the three outcome measures on the quantitative variables, the part of estimated total losses attributable to soft information, and either indicators for having a tough/easy examiner or the indicators for having a tough/easy examiner interacted with the soft information residual (results not shown). We do not find any systematic evidence that having a tougher or easier examiner made a difference for the three outcomes. Thus, we do not believe it is necessary to include examiner fixed effects in our reported results.

\footnotetext{
${ }^{19}$ We do not know very much else about these individuals, such as their experience when conducting the examinations. The Comptroller did include a list of examiners in his 1892 Annual Report and again in the 1902 Report. (We have not been able to locate similar lists in other years.) Of the 41 examiners listed in 1892, only 6 of them were still examiners in 1902. This turnover suggests that the tenure of the examiners was fairly moderate.
} 


\section{Discipline provided by examiners on poorly performing banks}

In the previous sections, we have found that that both the hard and soft information in the examination reports were useful in constructing loss estimates, and that these estimates are indicative of the condition of the bank. Here we consider whether the examiners were able to use this information to push for corrective behavior to promote the health and resiliency of National banks. We investigate whether and how examiners affected the behavior of the banks that they examined.

When an examiner had concerns about a bank and expected that losses were likely to be particularly large, there were a limited number of actions he could recommend, which were part of the statutory authority of the OCC. If the bank was found to have violated certain rules, such as its reserve requirement, the bank was not supposed to make new loans or pay dividends; the examiner may have been able to point out such a circumstance. If the bank was found to have a capital impairment - estimated losses exceeded the surplus and undivided profits - the Comptroller could require an assessment against shareholders to pay the deficiency or could appoint a receiver if the deficiency was not remedied (or if the bank was deemed insolvent). ${ }^{20}$

We find that, in practice, the examiners made other recommendations even though those recommendations did not flow from any explicit statutory backing. Some recommendations were mild, such as suggesting that the bank use a more modern bookkeeping system. On the other end of the spectrum, the examiner might recommend that the bank charge off bad assets by writing-down the value of its capital stock. The most common recommendation was that the bank skip paying a dividend, even if the reserve requirement was met, and instead use its earnings to charge off bad assets or to rebuild the surplus and undivided profits of the institution. Out of our sample of 205 institutions, this course of action was recommended 33 times, for about 15 percent of the sample. More severe recommendations, such as writing-down capital or making assessments against shareholders, were recommended for 8 of the institutions.

To understand whether recommendations for corrective action grounded in loss estimates were effective in improving the health and resilience of banks, we consider several aspects of the

\footnotetext{
20 The Comptroller could also allow the bank to voluntarily liquidate or write-down the value of its capital. See Comptroller of the Currency (1887, p.91).
} 
disciplinary process. We first consider whether the assessment the examiner provided affected whether that same examiner visited the bank subsequently. Finding that the examiners were more likely to be replaced if they provided high loss estimates might indicate that they were less able to discipline the bank. In the Appendix, we show that this was not the case; negative assessments had no effect on examiner turnover.

Next, we consider how the examiner's recommendation affected the behavior of the bank. When the examiner recommended not paying a dividend, the intent was that the bank would instead use the increased retained earnings to fund the charge off some of its bad assets. We look at whether a recommendation resulted in such behavior. Finally we look at whether there is an observable connection between the recommendation of the examiner and market discipline in the market for bank liabilities. In particular, we examine whether the interest rates the bank paid on its overall funding base, or on the funds it borrowed using rediscounts and bills payable, which may have been particularly sensitive to the condition of the bank, were affected by a decision to not pay dividends.

When investigating the disciplinary aspects of the examination process, we look at how a reported problem in an initial examination filing, which we refer to as the baseline exam, is related to information reported in the subsequent exam. When considering this subsequent exam, we exclude cases where the next examination is of a closed bank, as these may well differ from a normal bank examination. As an alternative, we also looked at how the results of the examination preceding the baseline exam affected the responses in the baseline exam. Changes in the variables reported on the examination form in earlier years make it difficult to control for the condition of the bank prior to the baseline examination. Nevertheless, results using the data that are available from the earlier reports are quite similar to the ones reported here.

\subsection{Examiner recommendations and subsequent action}

We examine how banks responded to the recommendation that they not pay dividends, and to examiners' recommendations that they charge off bad assets. We first focus on whether or not the subsequent exam reported that the bank had not paid dividends in the past six months. We regress an indicator for whether the bank paid such a dividend on an indicator for whether the examiner had recommended that the bank skip paying the dividend. We are interested in 
whether the recommendation of the examiner influenced the decision of the bank to skip the dividend above and beyond what the bank might have done itself based on its own assessment of its condition. ${ }^{21}$ In order to do so, we include in our regressions the quantitative indicators of bank health that we used previously.

Our results, reported in Table 8, show that banks for which the examiner recommended a suspension of dividends were less likely to have paid a dividend in the past six months. This is true even after controlling for other variables reflecting the condition of the bank.

The examiner intended that the funds not being used to pay dividends would instead be used to fund charge-offs of bad loans. We test whether the charge-off rate was indeed higher for banks for which the examiner recommended that the dividend not be paid. A positive result here implies two things. First, it implies that the bank had sufficient earnings to be able to charge off bad assets; if the banks had no earnings, then it could not charge off any bad assets. Second, a positive result implies that the bank made a choice to dedicate those earnings to charging off the bad assets. While we know from the previous result that the dividend suspending bank did not pay any funds (if available) as dividends, the bank could instead have opted to place those funds into its surplus and undivided profits. Recall that the estimated losses are the opinion of the examiner. If the bank disagreed, then it could comply with the recommendation of not paying dividends while expecting to pay out dividends in the future once the losses expected by the examiner did not materialize.

Our measure of the charge-off rate is based on examiner reports' indications of the amount of losses that the bank had charged off, any premiums charged off, and any decreases in value of assets charged off since the last examination. The charge-off rate is the sum of these charge-off amounts divided by the assets at the time of the last report. We then regress this charge-off rate on whether the examiner recommended that the bank not pay dividends.

The recommendation to suspend dividends was based on the examiner's estimates of the expected losses the bank would incur. One might expect that if a bank had more observably bad assets, such as elevated levels of other real estate owned, then the bank itself would prefer to

${ }^{21}$ Moreover, the examiner could only recommend the suspension of dividends. For a recommendation to have had stronger legal force, the Comptroller would need to issue a letter to the bank. 
charge-off more bad assets. Thus, in order to see whether the recommendation by the examiner might have resulted in charge-offs above and beyond what the bank might have opted to do itself, we again include in our regressions the quantitative measures of condition, public and private, as well as locational factors that we used previously. As a further check for whether it was the examiner's recommendation that mattered, we test an alternative specification in which we use the measure of the examiner's soft information component of estimate of losses from the decomposition analysis, rather than the indicator for recommending the suspension of dividends.

The results confirm that the examiner was able to push the bank both to suspend dividends and to charge-off more bad assets. In Specification 1 of Table 9, we see that banks for which the examiner had recommended that dividends not be paid tended to have higher writedown rates. In fact, the estimated coefficient indicates that at such banks the write-down rate was almost twice as high as the average rate of 0.8 percent. Further, we find that the judgmental soft information part of the examiner's loss estimate is also associated with a higher charge-off rate even controlling for other factors related to condition. In Specification 2, we find that the measure of losses based on subjective information also tended to result in higher charge-offs. These results provide further support for the idea that the examiner's recommendation provided a push for the bank to change its behavior. Interestingly, we don't find that many of our control variables are significant. We do, however, find that banks that had an active discount committee to review loans tended to have lower write-down rates.

Our finding that examiners were able to pressure banks to reduce bad assets through write downs are consistent with the narratives provided by the examiners about their impact of the behavior of banks:

This is one of the largest and best reputed banks in the city. I frankly told the president and cashier that were it not that I know from general results that the bank was perfectly solvent the appearance of the paper, if judged by comparison with other banks, would give me a strong suspicion otherwise. I told them that their paper looked on its surface about the worst of any in my district. These open expressions spurred them on to a betterment of the appearance of the loans as a body...At the urgent request of the president and cashier, I remained in the bank for two days during which time notices were sent out and considerable technically bad and overdue paper was collected or put in better shape...(Examination report of First National Bank, Los Angeles, charter 2491, 12/31/1891) 
Our results about the change in behavior at the banks must be compared to our results regarding the forecasting power of the decomposed parts of the loss estimates. With respect to bank closure, given that the examinations typically happened only shortly before the panic, it is likely that the banks did not have much time to substantially change their behavior. Thus, we can be fairly confident that the decomposed loss estimates are predictive of closure rather than causal. For the change in other real estate owned, it is striking that even though we find that examiner recommendations of skipping a dividend resulted in a higher charge-off rate, the amount of these bad assets still increased. Presumably they would have increased more in the absence of the examiners' encouraging banks to charge them off.

\subsection{Market discipline}

Not paying dividends was potentially a signal to the stockholders of the bank that there were problems with the bank's performance. (It was not a perfect signal however. While low profitability was the most common reason for not paying a dividend, there were other reasons. For example, newly chartered banks tended not to pay dividends as they sought to grow their surplus in support of future loan expansion.)

As the suspension of a dividend was not a common event, it seems likely that the suspension of a dividend would have been noted by market participants. ${ }^{22}$ Indeed, examiners reported some discussions with managers of troubled banks in which those managers expressed concerns about potential reputational consequences of omitting the dividend. We test whether banks that did not pay dividends suffered serious enough consequences that the suspension of dividends resulted in the banks paying higher interest rates on their funding generally, or in the in the interbank market, where lenders are potentially more informed. Furthermore, because the maturities of rediscounts and bills payable were shorter, those sources of funds may have been able to react more quickly to information about dividends. Finding evidence that skipping dividends raised banks' funding costs would suggest that the examination process provided a public signal about the quality of the bank in a way that was reinforced by market discipline in the market for bank liabilities.

\footnotetext{
${ }^{22}$ Other researchers have found that the suspension of dividends was an important signal of condition in this era. For instance, Riddiough and Thompson (2016) find that that equity market participants used the suspension of dividends as a signal about the quality of firms around the time of the collapse of Ohio Life in 1857.
} 
We compute the weighted average cost of funds that banks paid using the rates the examiner reported that the bank paid on interbank deposits, on retail CDs, and on bills payable and rediscounts as of the baseline examination report; the examiners reported that banks paid no interest on checking deposits. (Not all these rates were reported by all examiners so the sample is reduced slightly due to missing data.) We multiply these rates by the respective amounts of these liability items listed on the balance sheet and divide by the total of these items. We also look separately at the rates banks paid on bills payable and rediscounts.

We then regress these measures of funding cost on whether the bank had omitted its recent dividend payment, including call report variables that would have been observable to other banks (using the 1891 call report as the 1892 information would generally not have been available yet) and locational controls. As reported in Table 10, banks that had omitted their most recent dividend payment tended to pay higher rates on their debt, and paid higher rates to borrow from other banks, controlling for other public indicators of their condition. Thus, it appears that the suspension of dividend payments triggered by a poor examination report contributed to disciplining of the bank in the debt markets, and in particular, in the interbank market.

\section{Conclusion}

In this paper, we find that the subjective information gathered by the bank examiners of the national banking era while conducting their examinations was important in shaping their overall assessments of the bank and were informative about the condition of the bank. We find that the part of overall expected losses that we attribute to this subjective information were useful in predicting whether a bank would fail in the panic, how profitable it would be in the next couple years, and how the banks' loans would perform. We also find that the private quantitative information collected during examinations was informative about the health of the bank. The information that was valuable was not limited just to additional measures regarding the assets of the bank, but included information about the quality of the management and corporate governance of the bank.

We find that examiners were able to use the results of the examination process to improve the health of the banks. Recommendations by examiners that a bank's poor condition 
warranted the suspension of a dividend appear to have prompted many banks to shift the use of their earnings from dividend payouts to funds that could be used to charge off bad assets.

We also find evidence that the suspension of dividends as a consequence of a bad examination report may have affected banks through market discipline in the market for bank liabilities. Dividend suspending banks faced higher debt funding costs. 


\section{Appendix}

Here we consider two points referenced in the text: (1) whether the sequence of examination within a city gave rise to window dressing that might bias the relationship between examination measures and bank condition, and (2) whether the probability of an individual examiner returning to examine a bank was affected by the content of the prior examination report.

\section{Window Dressing}

The incentive to window dress might be reduced to the extent that the examiner did not review all banks in the larger cities in the same visit. Nevertheless, to check for evidence of window dressing, we look at whether the first bank in the town to be examined had systematically different balance sheet characteristics than the banks that were examined soon thereafter. As the examiner might not examine all the banks in a town in a single visit, we consider a bank to be the first to be examined if no bank in the town had been examined in previous six months and to be a subsequent bank if another bank had been examined within the past six months, although for nearly all banks considered to be subsequent another bank had been examined in the town within the past two days.

Our comparison of the findings of the examiners for the first banks examined in a town and the other banks is reported two groups of banks is in Table A1. We generally find little difference between the first bank examined and the banks examined subsequently. The share of banks that are deficient in their cash reserve is almost identical, as was the share of banks with loans in excess of the legal limit. About the same share of banks reporting that they used borrowed money, a practice that was frowned upon by the examiners (if anything, a higher share of banks that were examined after the examiner had been in town for a while were found to be using borrowed money). The one place where we do see some evidence of window dressing is

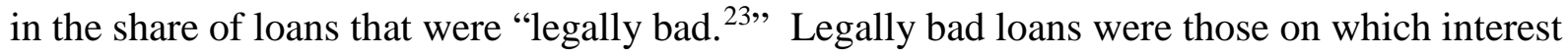
was past due for a period of six months, unless they were well secured and in the process of collection (Coffin 1890, Alcorn 1908).” generally meaning that they were past due by some

\footnotetext{
${ }^{23}$ Section 5204 of the Revised Statues
} 
period of time or inadequately secured. Thus it appears that banks did make an effort to renew loans or gather more collateral once the examiner appeared in town, but otherwise efforts to window dress appear to have been minimal. ${ }^{24}$

\section{Loss estimates and examiner turnover}

As part of our analysis of the examination process, we considered whether examiner turnover might be associated with reduced discipline on banks. In particular, in light of the heterogeneity of examiners' opinions, we consider here whether the rotation of examiners may have depended on the severity of their prior reports. We start by looking at whether examiners that noted larger expected losses were more or less likely to revisit the bank. In particular, we test whether the ratio of estimated losses to assets reported by the examiner for the baseline examination affected the likelihood that the same examiner was also the examiner for the subsequent examination. If examiners pointing to problems were less likely to return, then the bank may have been willing to take the chance that the next examiner might provide a more favorable report. However, as shown in Table A2, we find no evidence that this was the case. There appears to have been little association between expected losses and whether the examiner returned. ${ }^{25}$ Thus, we find no evidence that examiner turnover would have been associated with reduced discipline.

\footnotetext{
${ }^{24} \mathrm{We}$ also looked to see whether more troubled banks were examined first. We did not find any evidence of differences in estimated losses between banks examined first and banks examined subsequently, which suggests that troubled banks were not examined first. We did find that examinations of troubled banks typically took longer, usually an extra day or so.

${ }^{25}$ If we consider the losses reported on the previous exam and whether that examiner saw the bank in the baseline exam, we find that a bank was less likely to have a change in the examiner between the two reports if the examiner in the prior examination had made a higher estimate of losses. This, if anything, would have increased the discipline provided by the examiners.
} 


\section{References}

Alcorn, Edgar (1908). The Duties and Liabilities of Bank Directors, Financial Publishing Company: Columbus, $\mathrm{OH}$.

Berger, Allen N. and Sally M. Davies (1994). “The Information Content of Bank Exams,” Bank Structure and Competition, Federal Reserve Bank of Chicago, May.

Calomiris, Charles W. and Mark Carlson (2014). "National Bank Examinations and Operations in the Early 1890s,” Federal Reserve Finance and Economics Discussion Series 2014-19.

Calomiris, Charles W. and Mark Carlson (2016). "Corporate Governance and Risk Management at Unprotected Banks: National Banks in the 1890s.” Journal of Financial Economics.

Calomiris, Charles W., Florian Heider, and Marie Hoerova (2014). “A Theory of Bank Liquidity Requirements," unpublished mimeo.

Calomiris, Charles W., Mason, Joseph (1997). “Contagion and Bank Failures during the Great Depression: the June 1932 Chicago Banking Panic,” American Economic Review 87, 863-883.

Calomiris, Charles W. and Joseph Mason (2003). "Fundamentals, Panics, and Bank Distress During the Depression,” American Economic Review, 93(5): 1615-1647.

Carlson, Mark (2005). “Causes of Bank Suspension in the Panic of 1893,” Explorations in Economic History, January, vol. 42(1), pp. 56-80.

Coffin, George (1896). Handbook for Bank Officers, McGill and Wallace: Washington DC.

Comptroller of the Currency $(1887,1889,1890,1891)$. Annual Report of the Comptroller of the Currency, U.S. Government Printing Office, Washington D.C.

Crays, Dwight (1941). Bank Supervision in the United States, Board of Governors of the Federal Reserve mimeo.

DeYoung, Robert, Mark Flannery, William Lang, and Sorin Sorescu (1998). “The Informational Advantage of Specialized Monitors: The Case of Bank Examiners,” mimeo, Federal Reserve Bank of Chicago.

Flannery, Mark, Beverly Hirtle, Anna Kovner (2017). "Evaluating the Information in the Federal Reserve Stress Tests,” Journal of Financial Intermediation, vol. 29, pp. 1-18.

Goldsmith-Pinkham, Paul, Beverly Hirtle, and David Lucca (2016). "Parsing the Content of Bank Supervision,” Federal Reserve Bank of New York Staff Report, No. 770, March. 
Hirtle, Beverly, Anna Kovner, and Matthew Plosser (2016). "The Impact of Supervision on Bank Performance," Federal Reserve Bank of New York Staff Report, No. 778, March.

Ramirez, Carlos and Wayne Zandbergen (2013). "Anatomy of Bank Contagion: Evidence from Helena, Montana During the Panic of 1893” GMU Working Paper in Economics No. 1323.

Rezende, Marcelo and Jason Wu (2014). "The Effects of Supervision on Bank Performance: Evidence from Discontinuous Examination Frequencies,” Board of Governors of the Federal Reserve mimeo.

Riddiough, Timothy and Howard Thompson (2016). "When Prosperity Merges into Crisis: The Decline and Fall of Ohio Life, Political Economy of Bank Suspension, and the Panic of 1857.” Unpublished working paper, University of Wisconsin.

Robertson, R., 1995. The Comptroller and Bank Supervision, A Historical Appraisal. Office of the Comptroller of the Currency, Washington DC.

White, Eugene N. (1983). The Regulation and Reform of the American Banking System, 19001929. Princeton University Press: Princeton.

White, Eugene N. (1984). “A Reinterpretation of the Banking Crisis of 1930,” Journal of Economic History, vol. 44(1), pp. 119-138.

White, Eugene N. (2009). "Lessons from the History of Bank Examination and Supervision in the Unites States, 1863-2008," in Financial Market Regulation in the Wake of Financial Crises: The Historical Experience, Alfredo Gigliobiano and Gianni Toniolo (eds.) Banca d'Italia Eurosistema, pp. 15-44.

White, Eugene N. (2017). "Stabilizing the national banking system, 1864-1913: the role of bank examination," in Banking Modern America: Studies in Regulatory History, Jesse Stiller (ed.), Abingdon: Routledge, pp. 67-87. 
Table 1

List of variables

\begin{tabular}{|c|c|c|}
\hline Variable & Source & Description \\
\hline \multicolumn{3}{|l|}{ Loss related variables } \\
\hline Total losses to assets & Exam report & $\begin{array}{l}\text { Ratio of total losses on all balance sheet items as estimated } \\
\text { by the examiner relative to assets }\end{array}$ \\
\hline $\begin{array}{l}\text { Total losses attributed to public } \\
\text { information }\end{array}$ & Derived & Predicted value from Equation (1) \\
\hline $\begin{array}{l}\text { Total losses attributed to private } \\
\text { quantitative information }\end{array}$ & Derived & Predicted value from Equation (2) \\
\hline $\begin{array}{l}\text { Total losses attributed to soft } \\
\text { information }\end{array}$ & Derived & Residual from Equation (2) \\
\hline \multicolumn{3}{|l|}{ Public information } \\
\hline Log assets & Call report & Log of assets. \\
\hline Net worth to assets & Call report & Ratio of capital, surplus, and undivided profits to assets \\
\hline Cash to assets & Call report & Cash and legal tender to assets \\
\hline Due from banks to assets & Call report & Due from all banks (including reserve agents) to assets \\
\hline Other real estate owned to assets & Call report & Ratio of other real estate owned to assets \\
\hline $\begin{array}{l}\text { Individual deposits to total } \\
\text { liabilities }\end{array}$ & Call report & Share of liabilities consisting of deposits by individuals \\
\hline $\begin{array}{l}\text { Used bills or rediscounts to } \\
\text { borrow money }\end{array}$ & Call report & $\begin{array}{l}\text { Indicator that the bank borrowed using rediscounts or bills } \\
\text { payable }\end{array}$ \\
\hline Log age & $\begin{array}{l}\text { Comptroller \& } \\
\text { Rand McNally }\end{array}$ & $\begin{array}{l}\text { Log of the difference between } 1892 \text { and the time the bank } \\
\text { was established. }\end{array}$ \\
\hline Reserve city & Comptroller & Indicator that the city is a reserve city \\
\hline $\begin{array}{l}\text { Log county population } \\
\text { Log distance to New York }\end{array}$ & 1890 Census & $\begin{array}{l}\text { Log of county population } \\
\text { Log distance in miles to NY }\end{array}$ \\
\hline Mining in state & $\begin{array}{l}\text { Statistical } \\
\text { Abstract of the } \\
\text { US for } 1892\end{array}$ & $\begin{array}{l}\text { The state mined more than } \$ 1 \text { million in gold and/or silver } \\
\text { in } 1891 .\end{array}$ \\
\hline $\begin{array}{l}\text { Fraction state income from } \\
\text { agriculture }\end{array}$ & 1890 Census & $\begin{array}{l}\text { Value of agricultural products in the state divided by sum } \\
\text { of the value of agricultural products and of manufacturing } \\
\text { value added }\end{array}$ \\
\hline \multicolumn{3}{|l|}{ Private quantitative } \\
\hline Used CDs to borrow money & Exam report & $\begin{array}{l}\text { Indicator that the bank borrowed using interbank } \\
\text { certificates of deposit }\end{array}$ \\
\hline $\begin{array}{l}\text { Checking deposits to individual } \\
\text { deposits }\end{array}$ & Exam report & $\begin{array}{l}\text { Share of individual deposits consisting of checking } \\
\text { deposits }\end{array}$ \\
\hline Real estate loans to total loans & Exam report & Ratio of loans secured by real estate to total loans \\
\hline Demand loans to total loans & Exam report & $\begin{array}{l}\text { Ratio of loans callable at any time by the bank to total } \\
\text { loans }\end{array}$ \\
\hline "bad" loans to total loans & Exam report & $\begin{array}{l}\text { Ratio of "Bad debts, as defined in Section } 5204 \text { Revised } \\
\text { Statues" to total loans }\end{array}$ \\
\hline Management ownership & Exam report & $\begin{array}{l}\text { The share of stock owned by the top } 3 \text { bank managers - } \\
\text { the president, vice president, and cashier }\end{array}$ \\
\hline Frequency of board meetings & Exam report & $\begin{array}{l}\text { Log of the number of meetings held by the board each } \\
\text { year }\end{array}$ \\
\hline Active discount committee & Exam report & $\begin{array}{l}\text { Indicator variable for having an active independent } \\
\text { discount committee }\end{array}$ \\
\hline President bonded & Exam report & President posted a surety bond \\
\hline
\end{tabular}




\begin{tabular}{|c|c|c|}
\hline \multicolumn{3}{|l|}{ Outcome variables } \\
\hline & & Indicator that the bank suspended, failed, voluntarily \\
\hline Closed & Comptroller & $\begin{array}{l}\text { liquidated after filing the Sept. } 1892 \text { call report but before } \\
\text { Jan } 1,1894 \text {. }\end{array}$ \\
\hline $\begin{array}{l}\text { Percent change in surplus and } \\
\text { undivided profits }\end{array}$ & Call report & $\begin{array}{l}\text { The percent change in surplus and undivided profits from } \\
\text { September } 1892 \text { to October } 1894\end{array}$ \\
\hline $\begin{array}{l}\text { Change in other real estate } \\
\text { owned to assets }\end{array}$ & Call report & $\begin{array}{l}\text { The ratio of other real estate owned to assets in } 1894 \\
\text { minus the ratio of other real estate owned to assets in } 1892\end{array}$ \\
\hline \multicolumn{3}{|l|}{ Other variables } \\
\hline $\begin{array}{l}\text { Share of banks with deficient } \\
\text { cash reserves }\end{array}$ & Exam report & $\begin{array}{l}\text { Examiner indicated that the bank was deficient in its cash } \\
\text { reserve }\end{array}$ \\
\hline $\begin{array}{l}\text { Share of banks that made loans } \\
\text { in excess of legal limit }\end{array}$ & Exam report & $\begin{array}{l}\text { Examiner indicated that the bank made loans in excess of } \\
\text { the legal limit }\end{array}$ \\
\hline $\begin{array}{l}\text { Share of banks that used } \\
\text { borrowed money }\end{array}$ & Exam report & $\begin{array}{l}\text { Bank borrowed using bills payable, rediscounts, or CDs } \\
\text { issued to other banks }\end{array}$ \\
\hline Change in the examiner & Exam report & $\begin{array}{l}\text { Is the examiner the same on the subsequent examination as } \\
\text { on the baseline examination }\end{array}$ \\
\hline $\begin{array}{l}\text { Recent dividend subsequent } \\
\text { exam }\end{array}$ & Exam report & $\begin{array}{l}\text { Indicator for whether the bank reported on the subsequent } \\
\text { examination that it had paid dividends in the past six } \\
\text { months }\end{array}$ \\
\hline Recent dividend current exam & Exam report & $\begin{array}{l}\text { Indicator that the bank reported on the baseline } \\
\text { examination that it did not pay a dividend recently }\end{array}$ \\
\hline Charge-off rate & Exam report & $\begin{array}{l}\text { Amount reported as being charged off since last } \\
\text { examination on the subsequent examination divided by } \\
\text { assets on the baseline examination }\end{array}$ \\
\hline Average cost of funds & Exam report & $\begin{array}{l}\text { Weighted average cost of funds on checking deposits, } \\
\text { retail CDs, interbank deposits, and bills payable and } \\
\text { rediscounts. }\end{array}$ \\
\hline $\begin{array}{l}\text { Rate bank pays to borrow in the } \\
\text { interbank market }\end{array}$ & Exam report & $\begin{array}{l}\text { Median rate at which the bank borrows in the interbank } \\
\text { market on CDs, bills payable, and rediscounts }\end{array}$ \\
\hline $\begin{array}{l}\text { Examiner recommends no } \\
\text { dividend be paid }\end{array}$ & Exam report & $\begin{array}{l}\text { On the baseline exam report, the examiner recommended } \\
\text { that the bank not pay dividends }\end{array}$ \\
\hline
\end{tabular}


Table 2

Summary statistics

\begin{tabular}{|c|c|c|c|c|c|}
\hline Variable & Obs. & Mean & Std. Dev. & Min & Max \\
\hline \multicolumn{6}{|l|}{ Loss related variables } \\
\hline Total losses to assets & 205 & 1.2 & 3.8 & 0 & 32.1 \\
\hline Total losses attributed to public information & 205 & 1.2 & 2.4 & -2.2 & 14.8 \\
\hline Total losses attributed to private quant. information & 205 & 0 & 2.9 & -10.7 & 26.0 \\
\hline Total losses attributed to soft information & 205 & 0 & 2.7 & -10.9 & 21.0 \\
\hline \multicolumn{6}{|l|}{ Public information } \\
\hline Log assets & 205 & 14.1 & 0.84 & 12.0 & 15.9 \\
\hline Net worth to assets & 205 & 33.0 & 12.8 & 8.5 & 76.1 \\
\hline Cash to assets & 205 & 7.9 & 3.6 & 0.29 & 20.3 \\
\hline Due from banks to assets & 205 & 13.7 & 7.2 & 1.3 & 48.5 \\
\hline Other real estate owned to assets & 205 & 0.81 & 1.6 & 0 & 11.2 \\
\hline Individual deposits to total liabilities & 205 & 47.2 & 14.7 & 5.8 & 78.0 \\
\hline Used bills or rediscounts to borrow money & 205 & 0.19 & 0.39 & 0 & 1 \\
\hline Log age & 205 & 2.4 & 0.75 & 0.69 & 3.4 \\
\hline Reserve city & 205 & 0.37 & 0.48 & 0 & 1 \\
\hline Log county population & 205 & 4.4 & 0.83 & 2.7 & 5.9 \\
\hline Log distance to New York & 205 & 7.1 & 0.45 & 6.3 & 7.8 \\
\hline Mining in state & 205 & 0.21 & 0.41 & 0 & 1 \\
\hline Fraction state income from agriculture & 205 & 0.56 & 0.15 & 0.09 & 0.92 \\
\hline \multicolumn{6}{|l|}{ Private quantitative } \\
\hline Used CDs to borrow money & 205 & 0.15 & 0.35 & 0 & 1 \\
\hline Checking deposits to individual deposits & 205 & 74.1 & 19.9 & 17.5 & 100 \\
\hline Real estate loans to total loans & 205 & 3.6 & 6.1 & 0 & 54.7 \\
\hline Demand loans to total loans & 205 & 12.6 & 14.2 & 0 & 80.0 \\
\hline "bad" loans to total loans & 205 & 1.9 & 4.2 & 0 & 31.4 \\
\hline Management ownership & 205 & 24.2 & 22.5 & 0.5 & 96.7 \\
\hline Frequency of board meetings & 205 & 2.1 & 1.0 & 0.7 & 3.9 \\
\hline Active discount committee & 205 & 0.60 & 0.49 & 0 & 1 \\
\hline President bonded & 205 & 0.33 & 0.47 & 0 & 1 \\
\hline \multicolumn{6}{|l|}{ Outcome variables } \\
\hline Closed & 205 & 0.28 & .44 & 0 & 1 \\
\hline Percent change in surplus and undivided profits & 171 & -11.9 & 40.6 & -97.9 & 150 \\
\hline Change in other real estate owned to assets & 171 & 0.90 & 2.2 & -8.3 & 10.6 \\
\hline \multicolumn{6}{|l|}{ Other variables } \\
\hline Share of banks with deficient cash reserves & 205 & 0.18 & 0.38 & 0 & 1 \\
\hline Share of banks that made loans in excess of legal limit & 205 & 0.55 & 0.50 & 0 & 1 \\
\hline Share of banks that used borrowed money & 205 & 0.30 & 0.46 & 0 & 1 \\
\hline Change in the examiner & 205 & 0.44 & 0.49 & 0 & 1 \\
\hline Recent dividend subsequent exam & 195 & 0.40 & 0.49 & 0 & 1 \\
\hline Recent dividend current exam & 205 & 0.27 & 0.44 & 0 & 1 \\
\hline Charge-off rate & 142 & 0.84 & 1.1 & 0 & 6.1 \\
\hline Average cost of funds & 157 & 1.8 & 0.95 & 0.13 & 4.7 \\
\hline Rate bank pays to borrow in the interbank market & 68 & 5.8 & 1.4 & 0 & 9 \\
\hline Examiner recommends no dividend be paid & 205 & 0.16 & 0.37 & 0 & 1 \\
\hline
\end{tabular}


Table 3

Publicly observable hard information and total estimated losses

Dependent variable: Examiner’s estimated losses divided by assets

\begin{tabular}{|c|c|c|}
\hline & Coefficient & $\begin{array}{l}\text { Standard } \\
\text { error }\end{array}$ \\
\hline Log assets & 0.14 & $(0.40)$ \\
\hline Net worth to assets & $0.05 *$ & $(0.03)$ \\
\hline Cash to assets & -0.07 & $(0.08)$ \\
\hline Due from banks to assets & 0.03 & $(0.04)$ \\
\hline OREO to assets & $1.1^{* * *}$ & $(0.15)$ \\
\hline Indiv. dep. to assets & -0.02 & $(0.02)$ \\
\hline Uses bills of rediscount & 0.28 & $(0.65)$ \\
\hline Log age of bank & 0.01 & $(0.38)$ \\
\hline Bank in a reserve city & $-2.05 * * *$ & $(0.72)$ \\
\hline Log pop. of county & $1.1^{* *}$ & $(0.49)$ \\
\hline Log distance to New York & 0.69 & $(0.72)$ \\
\hline State has mining & $-1.7 * *$ & $(0.70)$ \\
\hline $\begin{array}{l}\text { Ratio of income from ag. to income from ag. } \\
\text { and manufacturing }\end{array}$ & $2.6^{*}$ & $(1.50)$ \\
\hline Constant & -12.1 & $(7.7)$ \\
\hline Observations & \multicolumn{2}{|l|}{205} \\
\hline Adjusted $\mathrm{R}^{2}$ & \multicolumn{2}{|l|}{0.36} \\
\hline F-statistic & \multicolumn{2}{|l|}{9.7} \\
\hline
\end{tabular}

Note: the symbols $*, * *$, and $* * *$ indicate statistical significance at the 10,5 , and 1 percent levels respectively. Standard errors are in parentheses. 
Table 4

Privately observable factors and the residual estimated losses

Dependent variable: Residual from equation 1

\begin{tabular}{|c|c|c|}
\hline & Coefficient & $\begin{array}{l}\text { Standard } \\
\text { error }\end{array}$ \\
\hline Borrows using CDs & $1.3^{*}$ & $(0.80)$ \\
\hline Checking to indiv. dep. & -0.01 & $(0.01)$ \\
\hline Real estate loans to total loans & $0.10^{*}$ & $(0.06)$ \\
\hline Demand loans to loans & -0.02 & $(0.01)$ \\
\hline Legally bad loans to loans & -0.08 & $(0.08)$ \\
\hline Mgmt ownership & -0.003 & $(0.01)$ \\
\hline Frequency of board meetings & $0.46^{*}$ & $(0.28)$ \\
\hline Active discount committee & $-1.1 * *$ & $(0.44)$ \\
\hline President bonded & $-0.79 * * *$ & $(0.31)$ \\
\hline Constant & 0.13 & $(1.0)$ \\
\hline Observations & \multicolumn{2}{|c|}{205} \\
\hline Adjusted $\mathrm{R}^{2}$ & \multicolumn{2}{|c|}{0.13} \\
\hline F-statistic & \multicolumn{2}{|c|}{4.35} \\
\hline
\end{tabular}

Note: the symbols $*{ }^{* *}$, and $* * *$ indicate statistical significance at the 10,5 , and 1 percent levels respectively.

Standard errors are in parentheses and are determined by bootstrapping the first and second stage jointly (estimation of equations 1 and 2) using 500 repetitions. 
Table 5

Decomposed loss estimates and outcome variables

\begin{tabular}{|c|c|c|c|c|c|c|}
\hline & \multicolumn{2}{|c|}{$\begin{array}{c}\text { Likelihood bank closes in } \\
1893 \\
\text { (probit) }\end{array}$} & \multicolumn{2}{|c|}{$\begin{array}{l}\text { Percent change in surplus } \\
\text { and undivided profits } \\
1892 \text { to } 1894 \\
\text { (OLS) }\end{array}$} & \multicolumn{2}{|c|}{$\begin{array}{c}\text { Change in other real estate } \\
\text { owned } 1892 \text { to } 1894 \\
\text { (OLS) }\end{array}$} \\
\hline & Coefficient & $\begin{array}{l}\begin{array}{l}\text { Standard } \\
\text { error }\end{array} \\
\end{array}$ & Coefficient & $\begin{array}{l}\text { Standard } \\
\text { error }\end{array}$ & Coefficient & $\begin{array}{l}\text { Standard } \\
\text { error }\end{array}$ \\
\hline $\begin{array}{l}\text { Portion of losses } \\
\text { attributed to soft } \\
\text { information }\end{array}$ & $0.14 *$ & $(0.08)$ & $-10.2 * * *$ & $(2.8)$ & $0.35 *$ & $(0.20)$ \\
\hline $\begin{array}{l}\text { Portion of losses } \\
\text { attributable to private } \\
\text { quantitative information }\end{array}$ & 0.12 & $(0.14)$ & $-15.8 * * *$ & $(4.0)$ & $0.49 *$ & $(0.30)$ \\
\hline $\begin{array}{l}\text { Portion of losses } \\
\text { attributed to public } \\
\text { information }\end{array}$ & $0.20 *$ & $(0.11)$ & $-12.0 * * *$ & $(4.4)$ & 0.03 & $(0.23)$ \\
\hline Constant & $-0.82 * * *$ & $(0.12)$ & -4.4 & $(4.1)$ & $0.98^{* * *}$ & $(0.18)$ \\
\hline Observations & \multicolumn{2}{|l|}{205} & \multicolumn{2}{|c|}{171} & \multicolumn{2}{|c|}{171} \\
\hline $\begin{array}{l}\mathrm{LR} \chi^{2} / \\
\text { F-statistic }\end{array}$ & \multicolumn{2}{|c|}{17.9} & \multicolumn{2}{|c|}{8.8} & \multicolumn{2}{|c|}{5.2} \\
\hline Pseudo / adjusted $\mathrm{R}^{2}$ & \multicolumn{2}{|c|}{0.07} & \multicolumn{2}{|c|}{0.12} & \multicolumn{2}{|c|}{0.07} \\
\hline
\end{tabular}

Note: the symbols $*, * *$, and $* * *$ indicate statistical significance at the 10,5 , and 1 percent levels respectively. The standard errors are in parentheses and are determined by bootstrapping the first, second, and third stages jointly (estimation of equations 1, 2, and 3) using 500 repetitions. 
Table 6

Value of soft information in an ex post framework

\begin{tabular}{|c|c|c|c|c|c|c|}
\hline & \multicolumn{2}{|c|}{$\begin{array}{l}\text { Likelihood bank closes } \\
\text { in } 1893 \\
\text { (probit) }\end{array}$} & \multicolumn{2}{|c|}{$\begin{array}{c}\text { Percent change in } \\
\text { surplus and undivided } \\
\text { profits } 1892 \text { to } 1894 \\
\text { (OLS) }\end{array}$} & \multicolumn{2}{|c|}{$\begin{array}{c}\text { Change in other real estate } \\
\text { owned } 1892 \text { to } 1894 \\
\text { (OLS) }\end{array}$} \\
\hline & Coefficient & $\begin{array}{l}\text { Standard } \\
\text { error }\end{array}$ & Coefficient & $\begin{array}{l}\text { Standard } \\
\text { error }\end{array}$ & Coefficient & $\begin{array}{l}\text { Standard } \\
\text { error }\end{array}$ \\
\hline Soft information & $0.26^{*}$ & $(0.16)$ & $-8.0^{* * *}$ & $(2.9)$ & $0.59 * * *$ & $(0.19)$ \\
\hline Borrows using CDs & 0.86 & $(0.65)$ & $-27.9 * *$ & (14.3) & 0.70 & (0.88) \\
\hline Checking to indiv. dep. & -0.02 & $(0.02)$ & $0.34^{*}$ & $(0.18)$ & $-0.02 *$ & $(0.01)$ \\
\hline Real est. loans to total loans & -0.05 & $(0.06)$ & $-2.1^{* *}$ & (1.1) & 0.11 & $(0.09)$ \\
\hline Demand loans to loans & $0.02 * *$ & $(0.01)$ & 0.37 & $(0.26)$ & -.02 & $(0.01)$ \\
\hline Legally bad loans to loans & 0.01 & $(0.08)$ & 0.14 & (1.5) & $-.18^{*}$ & $(0.11)$ \\
\hline Mgmt ownership & -0.01 & $(0.01)$ & 0.17 & $(0.20)$ & .003 & $(0.01)$ \\
\hline $\begin{array}{l}\text { Frequency of board } \\
\text { meetings }\end{array}$ & -0.04 & $(0.20)$ & -3.3 & (4.1) & .19 & $(0.25)$ \\
\hline Active discount committee & -0.07 & $(0.45)$ & 8.7 & $(7.7)$ & .09 & $(0.44)$ \\
\hline President bonded & 0.47 & $(0.42)$ & 2.8 & (7.6) & $-.97 * *$ & $(0.40)$ \\
\hline Log assets & $-0.45 *$ & $(0.26)$ & 1.4 & (6.3) & -.23 & $(0.34)$ \\
\hline Net worth to assets & $-0.04 *$ & $(0.02)$ & 0.12 & $(.44)$ & $.07 * *$ & $(0.03)$ \\
\hline Cash to assets & -0.05 & $(0.06)$ & 0.07 & $(1.2)$ & -.04 & $(0.05)$ \\
\hline Due from banks to assets & -0.03 & $(0.03)$ & -0.58 & $(0.32)$ & .01 & $(0.02)$ \\
\hline $\begin{array}{l}\text { OREO to assets/above } \\
\text { median OREO }\end{array}$ & $0.44 *$ & $(0.27)$ & $-8.7^{* *}$ & (4.3) & $.84^{* *}$ & $(0.40)$ \\
\hline Indiv. dep. to assets & $-0.04 *$ & $(0.02)$ & $0.81 * *$ & $(0.32)$ & -.001 & $(0.02)$ \\
\hline Uses bills of rediscount & 0.63 & $(0.67)$ & $-28.0 * *$ & $(10.6)$ & -.32 & $(0.68)$ \\
\hline Log age of bank & 0.14 & $(0.30)$ & $-10.5^{* *}$ & (5.4) & -.13 & $(0.25)$ \\
\hline Bank in a reserve city & $-1.1^{*}$ & $(0.67)$ & $23.0 * *$ & (11.5) & .06 & $(0.60)$ \\
\hline Log pop. of county & 0.37 & $(0.30)$ & $-14.0^{*}$ & $(8.0)$ & .54 & $(0.40)$ \\
\hline Log distance to New York & 0.45 & $(0.61)$ & -17.3 & $(12.2)$ & $1.04^{* *}$ & $(0.51)$ \\
\hline State has mining & 0.52 & $(0.61)$ & $24.4^{* *}$ & $(12.2)$ & -.61 & $(0.71)$ \\
\hline $\begin{array}{l}\text { Ratio of income from ag. to } \\
\text { income from ag. and manf. }\end{array}$ & -1.1 & $(1.4)$ & -30.7 & $(21.2)$ & .46 & $(1.2)$ \\
\hline Constant & 5.7 & $(6.0)$ & 129 & $(126)$ & -6.1 & $(5.7)$ \\
\hline Observations & \multicolumn{2}{|c|}{205} & \multicolumn{2}{|c|}{171} & \multicolumn{2}{|c|}{171} \\
\hline $\begin{array}{l}\text { LR } \chi^{2} / \\
\text { F-statistic }\end{array}$ & \multicolumn{2}{|c|}{83.4} & \multicolumn{2}{|c|}{2.6} & \multicolumn{2}{|c|}{2.9} \\
\hline Pseudo / adjusted $\mathrm{R}^{2}$ & \multicolumn{2}{|c|}{0.34} & \multicolumn{2}{|c|}{0.18} & \multicolumn{2}{|c|}{0.20} \\
\hline
\end{tabular}

Note: the symbols $*$, **, and *** indicate statistical significance at the 10,5 , and 1 percent levels respectively. The standard errors are in parentheses and are determined by bootstrapping the first, second, and third stages jointly (estimation of equations 1, 2, and 4) using 500 repetitions. 
Table 7

Were there difference across examiners?

(Tobit Regression)

Dependent variable: estimated losses to assets

\begin{tabular}{|c|c|c|}
\hline & Coefficient & $\begin{array}{l}\text { Standard } \\
\text { error }\end{array}$ \\
\hline Mr. Brush & -1.9 & $(1.4)$ \\
\hline Mr. Camp & 0.80 & $(1.2)$ \\
\hline Mr. Elary & -1.7 & $(1.4)$ \\
\hline Mr. Wilson & -1.0 & $(1.5)$ \\
\hline Mr. Stone & $6.6^{* * *}$ & $(1.5)$ \\
\hline Mr. Galb & 1.4 & $(1.4)$ \\
\hline Mr. Griff & 0.57 & $(1.4)$ \\
\hline Mr. Gannon & $4.1^{* *}$ & (1.8) \\
\hline Mr. Knight & 1.3 & $(1.4)$ \\
\hline Mr. McHugh & 0.03 & $(1.7)$ \\
\hline Mr. Lazear & -0.39 & $(1.6)$ \\
\hline Mr. Betts & 0.23 & $(1.6)$ \\
\hline Mr. Chamber & $-4.2 *$ & $(2.3)$ \\
\hline Mr. Wight & -2.2 & $(2.2)$ \\
\hline Borrows using CDs & $1.7^{* *}$ & $(0.73)$ \\
\hline Checking to indiv. dep. & -0.02 & $(0.02)$ \\
\hline RE loans to total loans & $0.13 * * *$ & $(0.03)$ \\
\hline Demand loans to loans & 0.01 & $(0.02)$ \\
\hline Legally bad loans to loans & -0.004 & $(0.07)$ \\
\hline Mgmt ownership & 0.001 & $(0.01)$ \\
\hline Frequency of board meetings & 0.33 & $(0.27)$ \\
\hline Active discount committee & $-0.95 *$ & $(0.55)$ \\
\hline President bonded & -0.71 & $(0.52)$ \\
\hline Log assets & 0.41 & $(0.42)$ \\
\hline Net worth to assets & 0.05 & $(0.04)$ \\
\hline Cash to assets & -0.05 & $(0.09)$ \\
\hline Due from banks to assets & 0.04 & $(0.04)$ \\
\hline OREO to assets & $0.90 * * *$ & $(0.17)$ \\
\hline Indiv. dep. to assets & -0.03 & $(0.03)$ \\
\hline Uses bills of rediscount & 0.86 & $(0.78)$ \\
\hline Log age of bank & -0.13 & $(0.45)$ \\
\hline Bank in a reserve city & -0.09 & $(0.83)$ \\
\hline State has mining & 0.57 & $(1.1)$ \\
\hline $\begin{array}{l}\text { Ratio of income from ag. to income from ag. } \\
\text { and manufacturing }\end{array}$ & -1.7 & (2.9) \\
\hline Constant & -4.1 & (7.3) \\
\hline Observations & \multicolumn{2}{|c|}{205} \\
\hline $\operatorname{LR} \chi^{2}$ & \multicolumn{2}{|c|}{168.7} \\
\hline Pseudo $\mathrm{R}^{2}$ & \multicolumn{2}{|c|}{0.18} \\
\hline
\end{tabular}

Note: the symbols *, **, and *** indicate statistical significance at the 10, 5, and 1 percent levels respectively. 62 observations were left-censored. Standard errors are in parentheses. 
Table 8

Impact of examiner recommendation on the likelihood that the bank pays a dividend (Probit)

Dependent variable: Did the bank pay a dividend in the past six months?

\begin{tabular}{|c|c|c|}
\hline & Coefficient & $\begin{array}{l}\text { Standard } \\
\text { error }\end{array}$ \\
\hline Examiner recommended no dividend & $-0.21 * *$ & $(0.10)$ \\
\hline Borrows using CDs & -0.13 & $(0.13)$ \\
\hline Checking to indiv. dep. & 0.003 & $(0.002)$ \\
\hline RE loans to total loans & 0.002 & $(0.01)$ \\
\hline Demand loans to loans & 0.003 & $(0.004)$ \\
\hline Legally bad loans to loans & 0.01 & $(0.01)$ \\
\hline Mgmt ownership & -0.0002 & $(0.002)$ \\
\hline Frequency of board meetings & -0.02 & $(0.05)$ \\
\hline Active discount committee & $0.15^{*}$ & $(0.08)$ \\
\hline President bonded & $-0.20 * * *$ & $(0.08)$ \\
\hline Log assets & $0.12 *$ & $(0.07)$ \\
\hline Net worth to assets & -0.006 & $(0.005)$ \\
\hline Cash to assets & 0.02 & $(0.01)$ \\
\hline Due from banks to assets & -0.01 & $(0.01)$ \\
\hline OREO to assets & -0.05 & $(0.05)$ \\
\hline Indiv. dep. to assets & -0.004 & $(0.004)$ \\
\hline Uses bills of rediscount & -0.10 & $(0.11)$ \\
\hline Log age of bank & 0.02 & $(0.06)$ \\
\hline Bank in a reserve city & 0.05 & $(0.13)$ \\
\hline Log pop. of county & $-0.19 *$ & $(0.10)$ \\
\hline Log distance to New York & $-0.49 * * *$ & $(0.13)$ \\
\hline State has mining & $0.43^{* * *}$ & $(0.13)$ \\
\hline $\begin{array}{l}\text { Ratio of income from ag. to income from ag. and } \\
\text { manufacturing }\end{array}$ & 0.44 & $(0.29)$ \\
\hline Observations & \multicolumn{2}{|c|}{145} \\
\hline $\begin{array}{l}\mathrm{LR} \chi^{2} / \\
\text { F-statistic }\end{array}$ & \multicolumn{2}{|c|}{56.7} \\
\hline Pseudo / adjusted $\mathrm{R}^{2}$ & \multicolumn{2}{|c|}{0.30} \\
\hline
\end{tabular}

Note: the symbols $*{ }^{* *}$, and $* * *$ indicate statistical significance at the 10,5 , and 1 percent levels respectively. We report marginal effects. Standard errors are in parentheses. 
Table 9

Examiner and charge-off rates

(Tobit)

Dependent variable: ratio of charge-offs to assets on last exam

\begin{tabular}{|c|c|c|c|c|}
\hline & \multicolumn{2}{|c|}{ Specification 1} & \multicolumn{2}{|c|}{ Specification 2} \\
\hline & Coefficient & Standard error & Coefficient & Standard error \\
\hline Examiner recommended no dividend & $0.79 * *$ & $(0.32)$ & & \\
\hline Soft information & & & $0.41 * * *$ & $(0.10)$ \\
\hline Borrows using CDs & -0.24 & $(0.38)$ & 0.19 & $(0.39)$ \\
\hline Checking to indiv. dep. & -0.001 & $(0.01)$ & -0.002 & $(0.006)$ \\
\hline RE loans to total loans & 0.003 & $(0.03)$ & 0.02 & $(0.03)$ \\
\hline Demand loans to loans & -0.01 & $(0.01)$ & -0.02 & $(0.01)$ \\
\hline Legally bad loans to loans & -0.02 & $(0.04)$ & $-0.11 * *$ & $(0.04)$ \\
\hline Mgmt ownership & 0.002 & $(0.005)$ & -0.002 & $(0.005)$ \\
\hline Frequency of board meetings & -0.11 & $(0.12)$ & 0.04 & $(0.12)$ \\
\hline Active discount committee & $-0.49 * *$ & $(0.23)$ & $-0.78 * * *$ & $(0.23)$ \\
\hline President bonded & 0.11 & $(0.22)$ & -0.09 & $(0.22)$ \\
\hline Log assets & 0.22 & $(0.21)$ & 0.12 & $(0.20)$ \\
\hline Net worth to assets & 0.01 & $(0.02)$ & 0.02 & $(0.02)$ \\
\hline Cash to assets & $-0.06^{*}$ & $(0.03)$ & $-0.07 * *$ & $(0.03)$ \\
\hline Due from banks to assets & -0.02 & $(0.02)$ & -0.01 & $(0.01)$ \\
\hline OREO to assets & 0.05 & $(0.14)$ & $0.50 * * *$ & $(0.16)$ \\
\hline Indiv. dep. to assets & 0.01 & $(0.01)$ & 0.003 & $(0.01)$ \\
\hline Uses bills of rediscount & 0.04 & $(0.33)$ & 0.14 & $(0.32)$ \\
\hline Log age of bank & 0.25 & $(0.17)$ & $0.28 *$ & $(0.17)$ \\
\hline Bank in a reserve city & 0.28 & $(0.37)$ & -0.42 & $(0.37)$ \\
\hline Log pop. of county & -0.02 & $(0.27)$ & 0.37 & $(0.25)$ \\
\hline Log distance to New York & $0.67 *$ & $(0.36)$ & $0.95^{* * *}$ & $(0.36)$ \\
\hline State has mining & 0.06 & $(0.38)$ & -0.19 & $(0.37)$ \\
\hline $\begin{array}{l}\text { Ratio of income from ag. to income } \\
\text { from ag. and manufacturing }\end{array}$ & -1.2 & $(0.75)$ & -0.28 & $(0.73)$ \\
\hline Constant & $-6.9 *$ & (3.8) & $-9.5 * *$ & (3.7) \\
\hline Observations & & & & \\
\hline $\operatorname{LR} \chi^{2}$ & & & & \\
\hline Pseudo $\mathrm{R}^{2}$ & & & & \\
\hline
\end{tabular}

Note: the symbols *, **, and *** indicate statistical significance at the 10,5 , and 1 percent levels respectively. Standard errors are in parentheses. 
Table 10

Impact of missing dividend payments on borrowing rate in the "borrowed funds" market

(OLS)

Dependent variable: weighted average rate paid of funds

\begin{tabular}{|c|c|c|c|c|}
\hline & \multicolumn{2}{|c|}{ Average cost of funds } & \multicolumn{2}{|c|}{$\begin{array}{l}\text { Rate on bills payable and } \\
\text { rediscounts }\end{array}$} \\
\hline & Coefficient & $\begin{array}{l}\text { Standard } \\
\text { error }\end{array}$ & Coefficient & $\begin{array}{c}\text { Standard } \\
\text { error }\end{array}$ \\
\hline $\begin{array}{l}\text { Bank had not paid a dividend in the } \\
\text { past six months }\end{array}$ & $0.38 * *$ & $(0.16)$ & $0.62 *$ & $(0.36)$ \\
\hline Log assets & 0.16 & $(0.11)$ & $.45^{*}$ & $(0.26)$ \\
\hline Cash to assets (1891) & $-0.07 * * *$ & $(0.02)$ & -0.05 & $(0.05)$ \\
\hline $\begin{array}{l}\text { Other real estate owned to assets } \\
\text { (1891) }\end{array}$ & -0.02 & $(0.05)$ & 0.09 & $(0.10)$ \\
\hline Log age of bank & 0.18 & $(0.12)$ & -0.42 & $(0.27)$ \\
\hline Bank in a reserve city & $0.39 * *$ & $(0.20)$ & 0.08 & $(0.49)$ \\
\hline Log pop. of county & $-0.40 * * *$ & $(0.14)$ & -0.44 & $(0.31)$ \\
\hline Log distance to New York & $1.0 * * *$ & $(0.24)$ & $1.2^{* *}$ & $(0.54)$ \\
\hline State has mining & $-0.58 * * *$ & $(0.20)$ & $-0.80 *$ & $(0.49)$ \\
\hline $\begin{array}{l}\text { Ratio of income from ag. to income } \\
\text { from ag. and manufacturing }\end{array}$ & -0.36 & $(0.44)$ & 0.16 & $(1.1)$ \\
\hline Crop moving season & $0.31 * *$ & $(0.14)$ & -.38 & $(0.32)$ \\
\hline Constant & $-5.7 * *$ & $(2.2)$ & -6.0 & $(5.4)$ \\
\hline Observations & \multicolumn{2}{|c|}{257} & \multicolumn{2}{|c|}{68} \\
\hline F-statistic & \multicolumn{2}{|c|}{8.2} & \multicolumn{2}{|c|}{3.7} \\
\hline Adjusted $\mathrm{R}^{2}$ & \multicolumn{2}{|c|}{0.33} & \multicolumn{2}{|c|}{0.31} \\
\hline
\end{tabular}

Note: the symbols *, ${ }^{* *}$, and $* * *$ indicate statistical significance at the 10,5 , and 1 percent levels respectively.

Standard errors are in parentheses. 
Table A1

Comparison of the first banks examined with subsequent banks examined

\begin{tabular}{l|cc}
\hline & First banks to be examined & $\begin{array}{c}\text { Subsequent banks to be } \\
\text { examined } \\
\text { (127 observations) }\end{array}$ \\
\hline $\begin{array}{l}\text { Share of banks with deficient } \\
\text { cash reserves }\end{array}$ & 0.17 & 0.19 \\
& $(0.38)$ & $(0.39)$ \\
$\begin{array}{l}\text { Average ratio of legally bad } \\
\text { loans to total loans }\end{array}$ & 2.7 & 1.4 \\
& $(5.6)$ & $(2.9)$ \\
$\begin{array}{l}\text { Share of banks that made loans } \\
\text { in excess of legal limit }\end{array}$ & 0.55 & 0.55 \\
& $(0.50)$ & $(0.50)$ \\
$\begin{array}{l}\text { Share of banks that used } \\
\text { borrowed money }\end{array}$ & & 0.27 \\
& 0.33 & $(0.45)$ \\
\hline
\end{tabular}

Note. Standard deviations in parentheses. 
Table A2

Relationship of reported losses and examiner turnover

(Probit)

Dependent variable: did the examiner change from one examination to the next

\begin{tabular}{l|cc}
\hline & Coefficient & $\begin{array}{c}\text { Standard } \\
\text { error }\end{array}$ \\
\hline Estimated losses on baseline exam to assets & 0.85 & $(3.73)$ \\
Log assets & $-0.16^{* *}$ & $(0.06)$ \\
Log age of bank & $0.15^{* * *}$ & $(0.06)$ \\
Bank in a reserve city & $-0.33^{* * *}$ & $(0.12)$ \\
Log pop. of county & 0.10 & $(0.08)$ \\
Log distance to New York & -0.08 & $(0.13)$ \\
State has mining & -0.07 & $(0.24)$ \\
Ratio of income from ag. to income from ag. \\
and manufacturing
\end{tabular}

Note: the symbols $*, * *$, and $* * *$ indicate statistical significance at the 10,5 , and 1 percent levels respectively. We report marginal effects. 